\title{
Structure, Velocities, and Faulting Relationships Beneath San Gorgonio Pass, California: Implications for Water Resources and Earthquake Hazards
}

by

R. D. Catchings, M. R. Goldman, G. Gandhok, E. Horta, M. J. Rymer, P. Martin, and A. Christensen

Open-File Report 99-568

10.
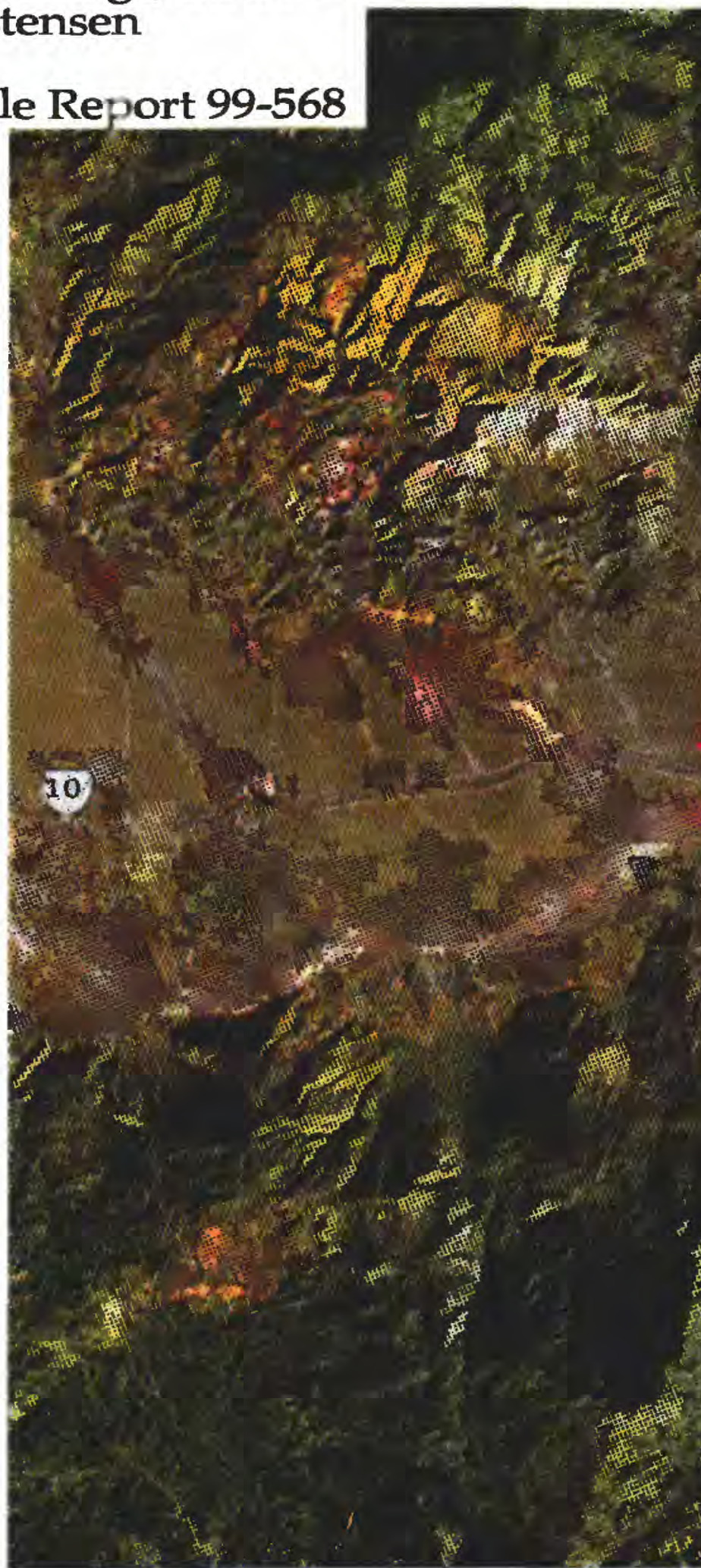

\section{San Gorgonio Bass}

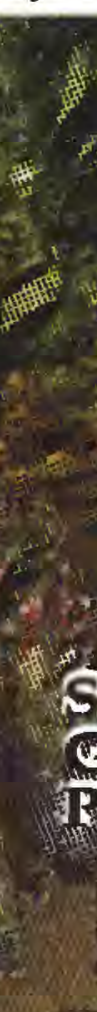




\section{Table of Contents}

Introduction $\quad 4$

Local Geology

Seismic Survey

Data Acquisition $\quad 9$

$\begin{array}{ll}\text { Shot and Geophone Locations } & 10\end{array}$

Seismic Data Processing

$\begin{array}{ll}\text { Seismic Refraction Velocity Analysis } & 10\end{array}$

Seismic Reflection Processing 11

Seismic Data

$\begin{array}{lr}\text { Profile SG } 1 & 12\end{array}$

$\begin{array}{ll}\text { Profile SG } 2 & 13\end{array}$

Interpretation

$\begin{array}{ll}\text { Profile SG } 1 & 21\end{array}$

Interpreted Reflection Section $\quad 21$

Interpreted Refraction Sections $\quad 21$

Interpreted Combined Refraction/Reflection 24

$\begin{array}{ll}\text { Profile SG } 2 & 27\end{array}$

Interpreted Reflection Section $\quad 27$

Interpreted Refraction Sections $\quad 30$

Interpreted Combined Refraction/Reflection $\quad 30$

Discussion and Conclusion $\quad 30$

Data Availability $\quad 41$

Acknowledgements $\quad 41$

References $\quad 41$

Appendix A SG 1 Receiver and shot locations $\quad 43$

Appendix B SG 2 Receiver and shot locations $\quad 47$

\section{List of Tables}

Table 1. Stratigraphy within the San Gorgonio Pass Region 8

Table 2. Acquisition Parameters $\quad 10$

\section{List of Figures}

Fig. 1a. Map showing regional of fault systems 5

Fig. 1b. San Gorgonio Pass location map with seismic profiles (SG-1, SG-2) 6 
Fig. 2. Relative geophone elevations versus distance along SG 1

Fig. 3. Geophone variation from a straight line along SG 1

Fig. 4. Relative shot point elevation vs. distance along SG 1

Fig. 5. Shot point variation from a straight line along SG 1

Fig. 6. Fold as function of CDP along SG $1 . \quad 16$

Fig. 7. Relative geophone elevations versus distance along SG $2 \quad 18$

Fig. 8. Geophone variation from a straight line along SG $2 \quad 18$

Fig. 9. Relative shot point elevation versus distance along SG 2

Fig.10. Shot point variation from a straight line along SG $2 \quad 19$

Fig.11. Fold as function of CDP along SG $2 \quad 20$

Fig.12. Stacked and migrated seismic reflection section along SG 1

Fig.13. Seismic velocity model along SG 1

Fig.14a. Combined seismic reflection image and velocity model along SG $1 \quad 25$

Fig.14b. Upper $400 \mathrm{~m}$ of the combined reflection/velocity image along SG $1 \quad 26$

Fig.15. Stacked and un migrated seismic reflection section along SG $2 \quad 28$

Fig.16. Stacked and migrated seismic reflection section along SG 2

Fig.17. Seismic velocity model along SG 2

Fig.18a. Combined seismic reflection image and velocity model along SG 2

Fig. 18b. Upper $450 \mathrm{~m}$ of the combined reflection/velocity image along SG 2

Fig.19. Interpretation and reflection image along SG 1

Fig.20. Line drawing of reflection image along SG 2 


\section{Introduction}

San Gorgornio Pass, California is an east-west-trending, topographically low-lying area between the San Bernardino and the San Jacinto Mountains, located approximately $120 \mathrm{~km}$ east of Los Angeles (Fig. 1a). To investigate issues related to groundwater resources and earthquake hazards in the San Gorgonio Pass area, the USGS conducted a high-resolution seismic imaging investigation there in August 1997.

Groundwater is important to the region because small cities located within the Pass (including Beaumont, Cherry Valley, the Morongo Indian Reservation, and Cabazon) and cities east of the Pass (including Desert Hot Springs, Palm Springs, and Indio) obtain much of their water supply from groundwater that flows through the Pass. Some of the cities in San Gorgonio Pass supplement naturally occuring groundwater by injecting water obtained from the Colorado River aqueduct into the subsurface. Water injected and stored during wet periods (principally winter) is extracted during dry periods (principally summer), however, ground-water flow from the recharge area and within the Pass must be understood to maximize recovery of the stored water. Groundwater flow through the Pass cannot be accurately determined at present because there are few wells and the subsurface structure and stratigraphy in the area is not well known. Of the wells in the region, the well nearest to our seismic survey (Well MS-25) was located less than 20 meters from profiles SG 1 and 2 (Fig. 1a).

Earthquake hazards associated with San Gorgonio Pass are important locally to the cities within and near San Gorgorio Pass for obvious reasons, but these hazards are important to greater southern California because major lifelines (including transportation, water, gas, and electrical lifelines) to the larger urban areas west of the Pass trend through San Gorgorio Pass. The greatest hazard in the Pass may be associated with three major fault systems: the San Andreas to the north in the San Bernardino Mountains, the San Gorgonio Fault Zone within San Gorgonio Pass (Matti and Morton, 1993), and the San Jacinto to the south within the San Jacinto Mountains (Fig. 1b). Although the San Andreas and San Jacinto faults may be larger, with greater regional hazards, unknown faults within the San Gorgonio Fault Zone may be particularly disruptive to the infrastructure within the Pass and to lifelines trending through the Pass due to their close proximity.

The seismic investigation presented in this report benefits both water-resource and earthquake hazards investigations by: (1) mapping subsurface stratigraphic horizons that outline the groundwater flow system and whose structural configuration influences 


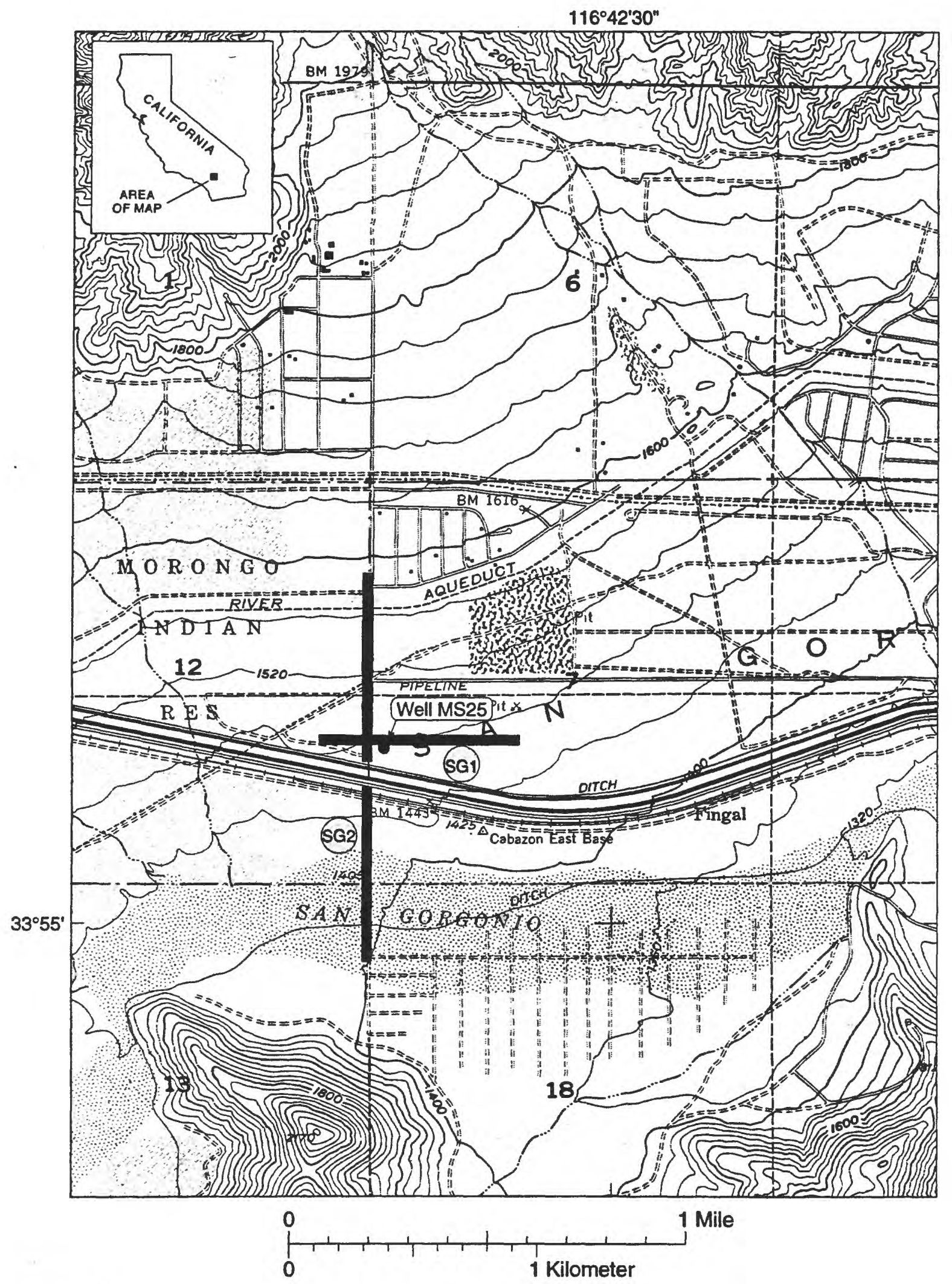

Figure 1a. Map of part of San Gorgonio Pass showing location of seismic lines (thick black lines) SG 1, oriented east-west, and SG 2, oriented north-south. 
ground shaking during earthquakes, (2) measuring seismic velocities and and basin geometries associated with unconsolidated sediments, both of which influence groundwater flow as well as ground shaking, and (3) locating faults that represent potential seismic sources and perhaps influence groundwater flow.

\section{Local Geology}

The valley within San Gorgonio Pass is covered at the surface by Quaternary sediments that include Holocene and Pleistocene alluvial fan deposits and Holocene active channels and washes (Matti et al., 1992). Allen (1957) suggests that the entire sequence of sedimentary rocks from just below the surface to bedrock are Tertiary and Quaternary sediments derived from continental sources, except those rocks of the Imperial Formation, which are derived from northward incursion of marine waters into the Salton depression to the south. The stratigraphic sequence within the San Gorgorio Pass is summarized in Table 1.

The lithology within the San Bernardino Mountains to the north and the San Jacinto Mountains to the south consists largely of metamorphic rocks that have been intruded by plutonic rocks of quartz monzonitic composition (Allen, 1957). The intrusive dikes include pegmatite dikes, migmatitic rocks (granitic composition), and plutonic quartz monzonite rocks. Allen (1957) describes these rocks as a "hybrid of types of varying composition and transitional boundaries" that resulted from complex faulting within the San Bernardino Mountains. To the south, the crystalline rocks of the San Jacinto Mountains are largely Mesozoic, Paleozoic, and PreCambrian? granitoid and pre-batholithic metasedimentary rocks (Matti et al., 1992), consisting largely of quartzo-feldspathic gneisses and schists, hornblende schists, phyllite, crystalline limestone, and quartzite (Fraser, 1931). The metasedimentary rocks are underlain by intrusive rocks that are predominantly of granodiorite composition (Allen, 1957).

San Gorgonio Pass is located in a particularly complex area of the San Andreas Fault system. Southeast of San Gorgonio Pass, the San Andreas Fault is split into two segments, the Mission Creek segment which trends north of San Gorgonio Pass within the San Bernardino Mountains, and the Banning segment which trends largely along the southern end of the San Bernardino Mountains (Fig. 1b). The Banning fault may be up to $100 \mathrm{~km}$ in length and has generated as much as $16-25 \mathrm{~km}$ of right lateral slip since the Miocene, but in the San Gorgonio Pass area, the Banning fault has been modified by Quaternary reverse, thrust, and wrench faults, the assemblage of which Matti et al.(1992) call the San Gregonio Pass fault zone (Fig. 1b). Right-lateral movement apparently 
Table: 1. Sequence and character of the Sedimentary rocks of San Gorgonio Pass (Allen, 1957).

\begin{tabular}{|c|c|c|c|}
\hline Formation & Age & $\begin{array}{l}\text { Max.thickness } \\
\text { (feet) }\end{array}$ & Lithology \\
\hline Alluvium & Recent & & $\begin{array}{l}\text { Unconsolidated stream gravels and low stream terrace } \\
\text { gravels }\end{array}$ \\
\hline -Unconformity- & --.----. & & \\
\hline Landslide deposits & Recent & & \\
\hline -Unconformity- & ---------- & & \\
\hline $\begin{array}{l}\text { Undifferentiated } \\
\text { terrace gravels }\end{array}$ & Quaternary & & $\begin{array}{l}\text { Terrace gravel and canyon-fill material of doubtful } \\
\text { correlation }\end{array}$ \\
\hline -Unconformity- & -....-- & & \\
\hline Burnt Canyon breccia & Quaternary & $100+$ & Dissected landslide deposit \\
\hline -Unconformity- & 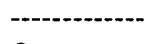 & & \\
\hline Heights Fanglomerate & Quaternary & 500 & $\begin{array}{l}\text { Tan to dark-brown, ill-sorted conglomerate, dominantly } \\
\text { dark clasts of gneissic rock }\end{array}$ \\
\hline -Unconformity- & -..-..-..- & & \\
\hline Cabezon & Quaternary & $1500+$ & Grey to tan ill-sorted conglomerate, rich in clasts of \\
\hline Fanglomerate & & & pegmatitic and granitic rocks \\
\hline -Unconformity- & -..--.--.-- & & \\
\hline Deformed gravels of & Quaternary & & Grey to tan ill-sorted conglomerate, rich in clasts of \\
\hline Whitewater river & $(?)$ & & pegmatitic and granitic rocks \\
\hline -Contact not exposed- & Plincene- & $1800+$ & Tan to grey sandstone siltstone and conolomerate rich \\
\hline $\begin{array}{l}\text { San Timoteo } \\
\text { Formation (?) }\end{array}$ & $\begin{array}{l}\text { Pliocene- } \\
\text { Pleistocene }\end{array}$ & $1800+$ & $\begin{array}{l}\text { in light-coloured clasts of granitic rocks; interbedded } \\
\text { fresh water limestone }\end{array}$ \\
\hline -Contact not exposed- & & & \\
\hline Painted Hill & Middle & $3400+$ & Light-grey sandstone and conglomerate, rich in clasts of \\
\hline Formation & Pliocene? & & $\begin{array}{l}\text { volcanic and granitic rocks:Ppc, resistant conglomerate } \\
\text { bed;Ppb, interlayered flows of olivine basalt;Ppd, } \\
\text { associated dykes }\end{array}$ \\
\hline Imperial Formation & $\begin{array}{l}\text { Lower } \\
\text { Pliocene? }\end{array}$ & 300 & $\begin{array}{l}\text { Tan to yellow marine sandstone, siltstone, and } \\
\text { shale;fossiliferous }\end{array}$ \\
\hline \multicolumn{4}{|l|}{ Hathaway Formation } \\
\hline Upper Member & $\begin{array}{l}\text { Lower } \\
\text { Pliocene? }\end{array}$ & 650 & $\begin{array}{l}\text { Grey, massive, ill-sorted conglomerate and brecchia, } \\
\text { rich in clasts of augen and flaser gneiss }\end{array}$ \\
\hline Lower Member & $\begin{array}{l}\text { Lower } \\
\text { Pliocene? }\end{array}$ & $1100+$ & $\begin{array}{l}\text { Light-grey sandstone, siltstone, conglomerate, and } \\
\text { fresh-water limestone }\end{array}$ \\
\hline \multicolumn{4}{|l|}{ Contact not exposed-- } \\
\hline $\begin{array}{l}\text { Coachella } \\
\text { fanglomerate }\end{array}$ & & & $\begin{array}{l}\text { massive conglomerate, locally rich in clasts of basalt } \\
\text { and dark-green gneiss;Mcb,interlayered flows of olivine } \\
\text { basalt;Mcd, associated dykes:Mcm, marker horizon }\end{array}$ \\
\hline Upper Member & Upper & $3750+$ & containing distinctive clasts \\
\hline & Miocene? & & $\begin{array}{l}\text { well-indurated masisve conglomerate, locally rich in } \\
\text { clasts of }\end{array}$ \\
\hline Lower Member & $\begin{array}{l}\text { Upper } \\
\text { Miocene? }\end{array}$ & 850 & olivine basalt:basal brecchia of grey schist fragments \\
\hline
\end{tabular}


continues near the southern end of the Banning fault and may be the source of the 1986 $M=5.9$, North Palm Springs earthquake, but the westernmost segment of the Banning fault may be inactive, as there is little evidence of ground ruptures during the Quaternary (Matti et al., 1992).

Understanding the complex faulting relationship within the San Gorgonio Pass region is made more difficult by the alluvial cover. Seismic studies, such as the one reported here, may help delineate some of the faulting relationships within the San Gorgonio Pass region.

\section{Seismic Survey}

\section{Data Acquisition}

In August 1997, the U. S. Geological Survey acquired two high-resolution seismic reflection and refraction profiles in San Gorgonio Pass (Fig. 1a,b). The seismic profiles (labeled SG 1 and SG 2) ranged in length from approximately $810 \mathrm{~m}$ to about $1577 \mathrm{~m}$ (Table 2). SG 1 was oriented approximately east-west, and SG 2 was oriented approximately north-south. The data were acquired using a shoot-through method, whereby, the geophones (i.e. the recording channels) remained stationary as shots were fired along the array. Approximately 4 seconds of data were recorded using a linear array of two to four Geometrics Strataview RX $60^{\mathrm{TM}}$ seismographs, each with 60 active channels. The data were stored on the hard drive of the seismograph during field acquisition and was later downloaded to $4 \mathrm{~mm}$ tape for permanent strorage in SEG-Y format.

Single-element, 40-Hz, vertical-component Mark Products L-40A ${ }^{\mathrm{TM}}$ geophones were spaced at $5 \mathrm{~m}$ along each of the profiles. Seismic sources consisted of explosive 1-lb ammonium nitrate charges in $\sim 2-\mathrm{m}$ deep-holes and were spaced at 10-m intervals along the profile. The sources were co-located with geophones at 1-m lateral offsets. Seismic sources and seismographs were triggered simultaneously by synchronized electronic clocks with accuracies of approximately $1 \mathrm{~ms}$.

Prior to acquiring the data, each recording site and shot point was measured with a meter tape and flagged to obtain the proper spacing. After the data were acquired, we used an electronic distance meter (EDM) to measure the recording sites and shot point locations with accuracies as great as $0.001 \mathrm{~m}$. 
Table 2. Acquisition parameters for San Gorgonio Pass seismic profiles. Distances are relative to the first shot point.

\begin{tabular}{|c|c|c|c|c|c|c|}
\hline Profile \# & Orientation & $\begin{array}{c}\text { Length of } \\
\text { Geophone } \\
\text { Profile (m) }\end{array}$ & $\begin{array}{c}\text { Length of } \\
\text { Shot Point } \\
\text { Profile (m) }\end{array}$ & No. of Shots & $\begin{array}{c}\text { No. of } \\
\text { CDP's }\end{array}$ & $\begin{array}{c}\text { Maximum } \\
\text { Fold }\end{array}$ \\
\hline SG 1 & W-E & 594.99 & 810.22 & 80 & 281 & 59 \\
\hline SG 2 & S-N & 1297.62 & 1577.41 & 135 & 576 & 119 \\
\hline & & & & & & \\
\hline
\end{tabular}

\section{Shot and Geophone Locations}

Variations in shot point and geophone locations and elevations can cause appreciable difficulty in stacking seismic reflection data and in accurately measuring the velocities if these variations are not included in processing the data. Large variations in line geometry may also result in data artifacts that are interpreted as structure. Therefore, we present the line geometries (see Appendices A-B) to aid in interpretation and reprocessing the seismic data.

To correlate seismic velocities and images with possible geometrical variations in the profile, we present graphical displays of the geometry along each profile, including sho* point and geophone elevations, lateral variations from straight lines of shot point and geophone arrays, and fold (described below). In many instances, abrupt changes in elevation can be correlated with faults or major changes in stratigraphy, but apparent faults or stratigraphic changes that correlate with significant or abrupt changes in shot point and geophone arrays or large jumps in fold may also be artifacts.

\section{Seismic Data Processing}

Both reflection and refraction data were available because the data were acquired using a shoot-through configuration. This type of data acquisition has numerous advantages over conventional data acquisition because detailed velocity data are available and folds are typically much greater for reflection stacks.

\section{Seismic Refraction Velocity Analysis}

For refraction data processing, we used a seismic tomographic inversion method developed by Hole (1992), whereby, first arrivals on each seismic trace were used to measure detailed velocities from depths ranging from about $1 \mathrm{~m}$ to approximately $300 \mathrm{~m}$ 
below the surface. For greater depths, velocities needed in seismic reflection stacking were determined using semblence and parabolic methods and from apriori knowledge of the local geology. As described below, we used the velocities derived from these methods to convert the reflection time-images to depth-images and, where necessary, to migrate the seismic reflection images.

\section{Seismic Reflection Processing}

Seismic reflection data processing was accomplished on a Sun Sparc $20^{\mathrm{TM}}$ computer using an interactive seismic processing package known as ProMAX ${ }^{\mathrm{TM}}$. The following steps were involved in data processing:

Geometry Installation

Lateral distances and elevations described above were used to define the geometrical set up of each profile. We installed the electronically-measured geometries into the ProMAX ${ }^{\mathrm{TM}}$ processing package for each profile separately so that shot and receiver elevations and locations could be included in the processing routine.

Trace Editing

Occasionally, bad coupling between the geophones and the ground, malfunctioning geophones, or cultural noise close to some seismic receivers resulted in unusually noisy traces at those locations, however, these traces were not unsuitable for all shot gathers. Therefore, independent trace editing was employed for each shot gather.

\section{Bandpass Filtering}

Most of the data of interest for seismic imaging and velocity measurement are well above $25 \mathrm{~Hz}$, and most of the undesirable seismic data, such as surface waves and shear waves, were well below $25 \mathrm{~Hz}$. Therefore, a bandpass filter with a low cut of $25 \mathrm{~Hz}$ was used to remove most surface and shear waves and cultural noise.

\section{F-K Filtering}

Not all surface waves were removed by simple bandpass filtering. To remove those surface waves and air waves that were not removed by bandpass filtering, we used a FK filter.

\section{Timing Corrections}

Although the shotgun source electronically triggers the seismographs, there are small ( $\sim 2 \mathrm{~ms})$ delays between the electrical trigger and the actual shotgun explosions. We corrected for the delays by removing a constant $2 \mathrm{~ms}$ from the start: time of each shotgather.

\section{Velocity Analysis}


Velocities in the shallow section $(\sim 1 \mathrm{~m}$ to $\sim 150 \mathrm{~m})$ were determined using velocity inversion techniques, but velocities in the deeper section were determined using shotgathers and CDP stacks.

\section{Elevation Statics}

Elevation statics were also employed to correct for variations in elevations using locations derived from electronic measurements and velocities derived from the refraction velocity analysis.

\section{Moveout Correction}

Due to progressively greater traveltimes for the seismic waves to reach sensors that were progressively farther from each shot point, there was a delay (moveout) for each seismic arrival on the seismic record. To sum (stack) the data at each common depth point (CDP), a correction was made for the moveout using velocities obtained from the velocity analysis.

\section{Velocity Inversion}

Velocities were measured from first arrivals of the seismic data using a computerized inversion routine developed by Hole (1992).

\section{Muting}

To remove refractions and other arrivals that were not completely removed using filtering techniques, we used trace muting before and after stacking.

\section{Stacking}

To enhance the seismic signal at each location, individual reflections were summed together in a process called stacking.

\section{Depth Conversion}

For stacked seismic reflection sections that were not migrated, we converted the time sections to depth sections using RMS velocities converted from the velocity analysis described above in the velocity section.

\section{Migration}

Due to the presence of numerous faults and diffraction points in the subsurface, diffraction hyperbolae were observed throughout the section. We used pre-stack migration to collapse the diffraction hyperbolae to better identify the major faults.

\section{Seismic Data}

\section{Profile SG 1}

Profile SG 1 was oriented approximately east-west and extended $810 \mathrm{~m}$ parallel to Interstate 10 (Fig. 1a). Two RX-60 seismographs with 120 live channels were utilized to record the data. Geophones and shots were spaced at 5-m and 10-m intervals, 
respectively. A shot was fired adjacent to every other geophone (laterally offset by $1 \mathrm{~m}$ ), and 11 shots were fired at each end of the recording array. Due to cultural features along the line (such as gas and utility lines), two shot point locations were not utilized along the seismic profile.

Geophones varied in elevation by no more than $7 \mathrm{~m}$ along the seismic profile, with elevations decreasing from west to east along the profile (Fig. 2). On seismic reflection sections, elevation is plotted relative to the topographically lowest geophone along the recording array, but because velocity information is available along the variation in topography, reflections along the topographic variation were included in the seismic reflection sections (e.g, no datum with reflections above topography removed). The geophone array varied by about $2 \mathrm{~m}$ from a straight line connecting the endpoints of the shotpoint array (Fig. 3); thus, relative to the entire length of the geophone array $(-595 \mathrm{~m})$, there was only about a $0.33 \%$ variation from a straight line. Therefore, it is unlikely that geometrical variations in the geophone array would cause artifacts in the data.

As the shot point array extended beyond the ends of the geophone array, the maximum variation in shot point elevations was greater than that of the geophone array. Shot point elevations varied by about $12 \mathrm{~m}$ along the shot-point array (Fig. 4), and relative to a straight line connecting the endpoints of the shot point array, shot points varied by about $2 \mathrm{~m}$ (Fig. 5). In terms of percentage of the entire length of the shot-point array, the $2-\mathrm{m}$ variation in linearity is about $0.25 \%$, which is far too little to cause artifacts in stacked sections.

Fold, ( the theoretical number of times a reflection occurs at a given location) along

SG 1 was smoothly varying because of the stationary recording array (Fig. 6). Maximum fold of about 59 was obtained near the center of the seismic profile and decreased to about 1 at the ends of the profile. Because maximum folds were near the middle of the seismic profile, the deeper structure is most reliably imaged near the center of the profile. However, the explosive sources used generate signals that are ususally strong enough to provide clear reflections to depths in excess of about $1 \mathrm{~km}$ with folds of about 1.

\section{Profile SG 2}

Profile SG 2 was oriented approximately south-north and extended $1577 \mathrm{~m}$ from near the northern end of the San Jacinto Mountains to just beyond the Colorado River aqueduct, north of Interstate 10 (Fig. 1a,b). Four RX-60 seismographs with 240 live channels were utilized to record the data. Geophones and shots were spaced at 5-m and 10$\mathrm{m}$ intervals, respectively, with shot points laterally offset by $1 \mathrm{~m}$ from every second geophone $(10 \mathrm{~m})$. A total of 135 shots were fired into the array, but there were about 24 


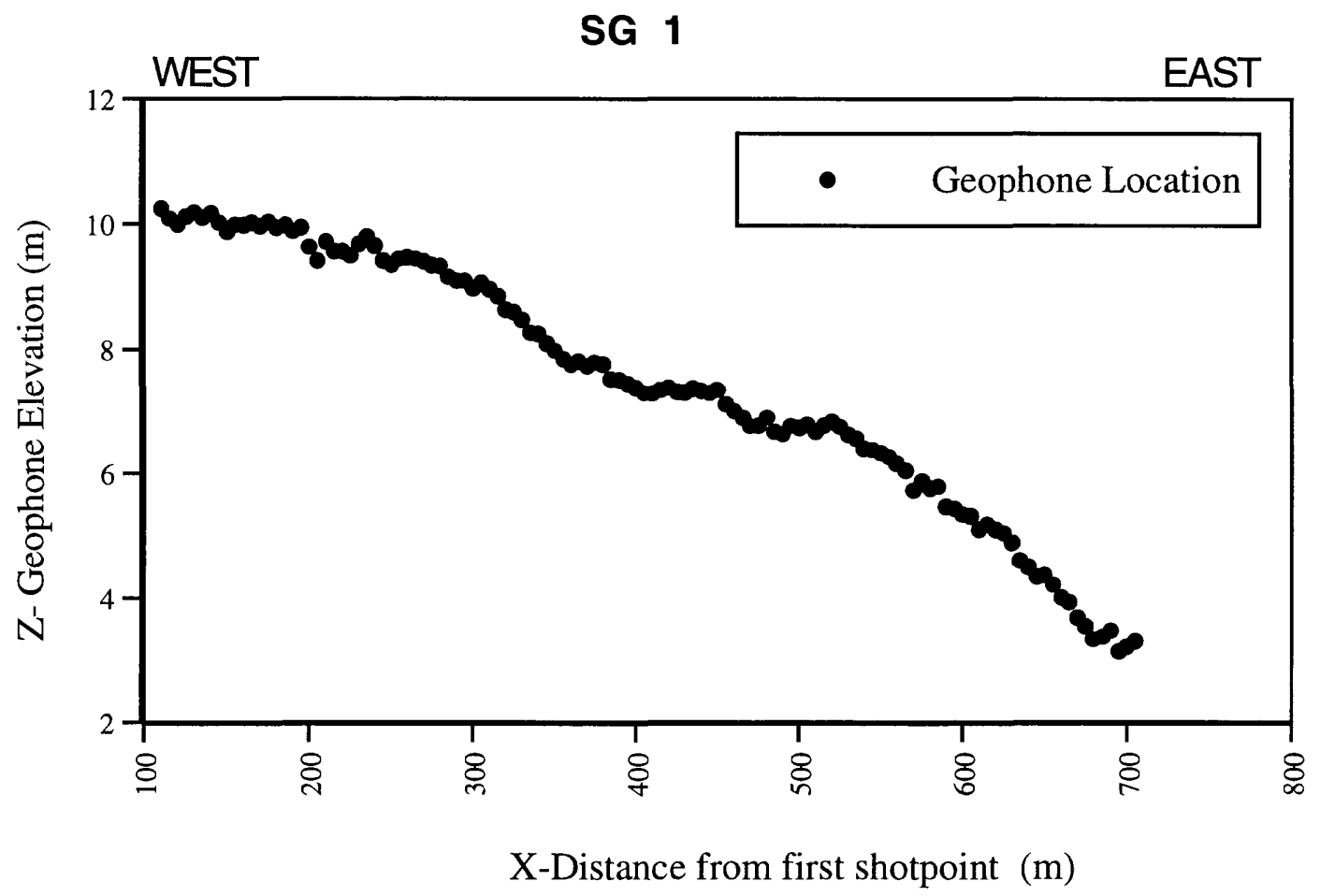

Figure 2. Geophone elevation along SG 1. Elevation is relative to the topographically lowest shotpoint.

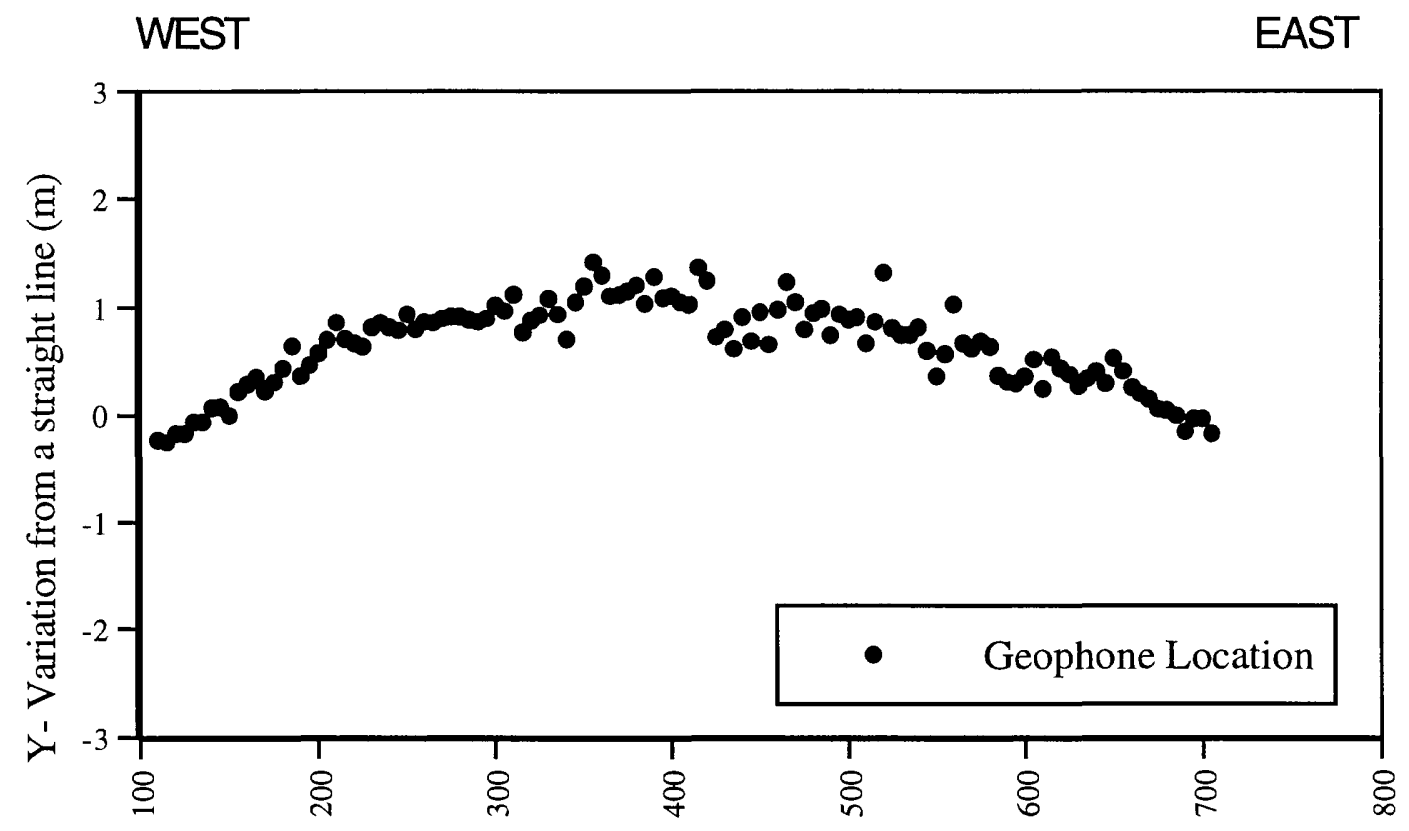

X-Distance from first shotpoint (m)

Figure 3. Geophone variation from a straight line connecting the first and last shot point along SG 1. 
SG 1

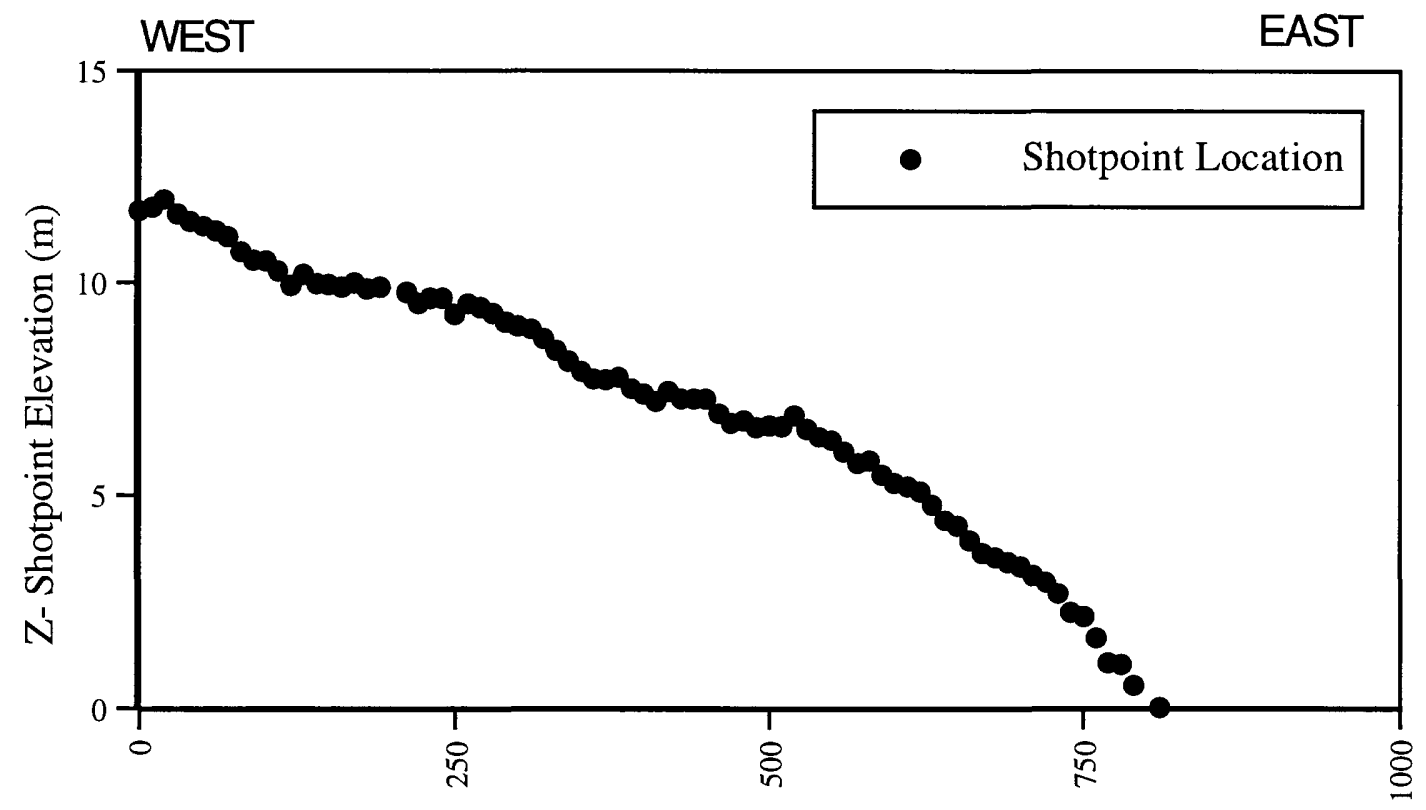

$\mathrm{X}$ - Distance from first shotpoint $(\mathrm{m})$

Figure 4. Shotpoint elevation along SG 1. Elevation is relative to the topographically lowest shotpoint.

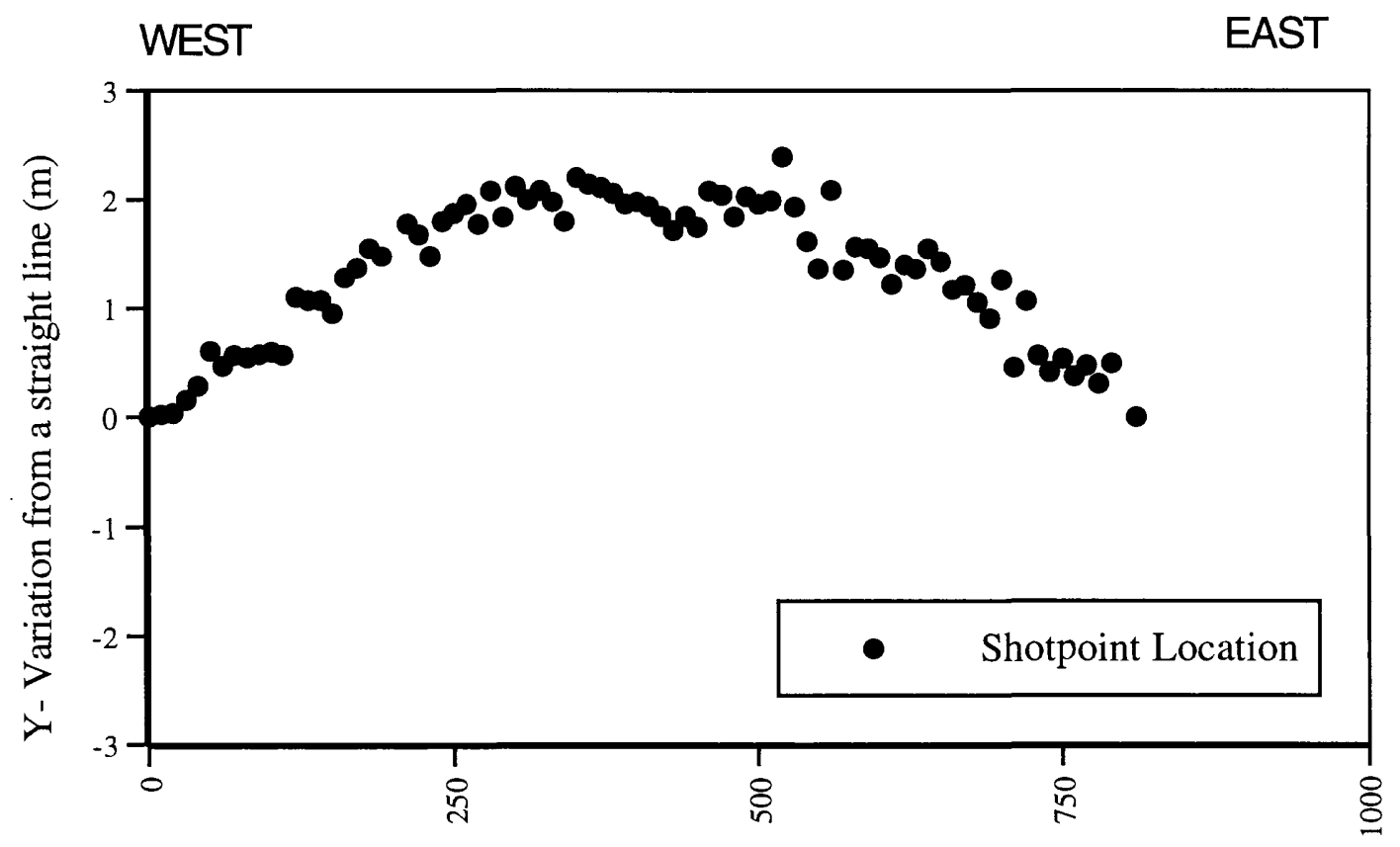

$\mathrm{X}$ - Distance from first shotpoint (m)

Figure 5. Shotpoint variation from a straight line connecting the first and last shotpoint along SG 1. 


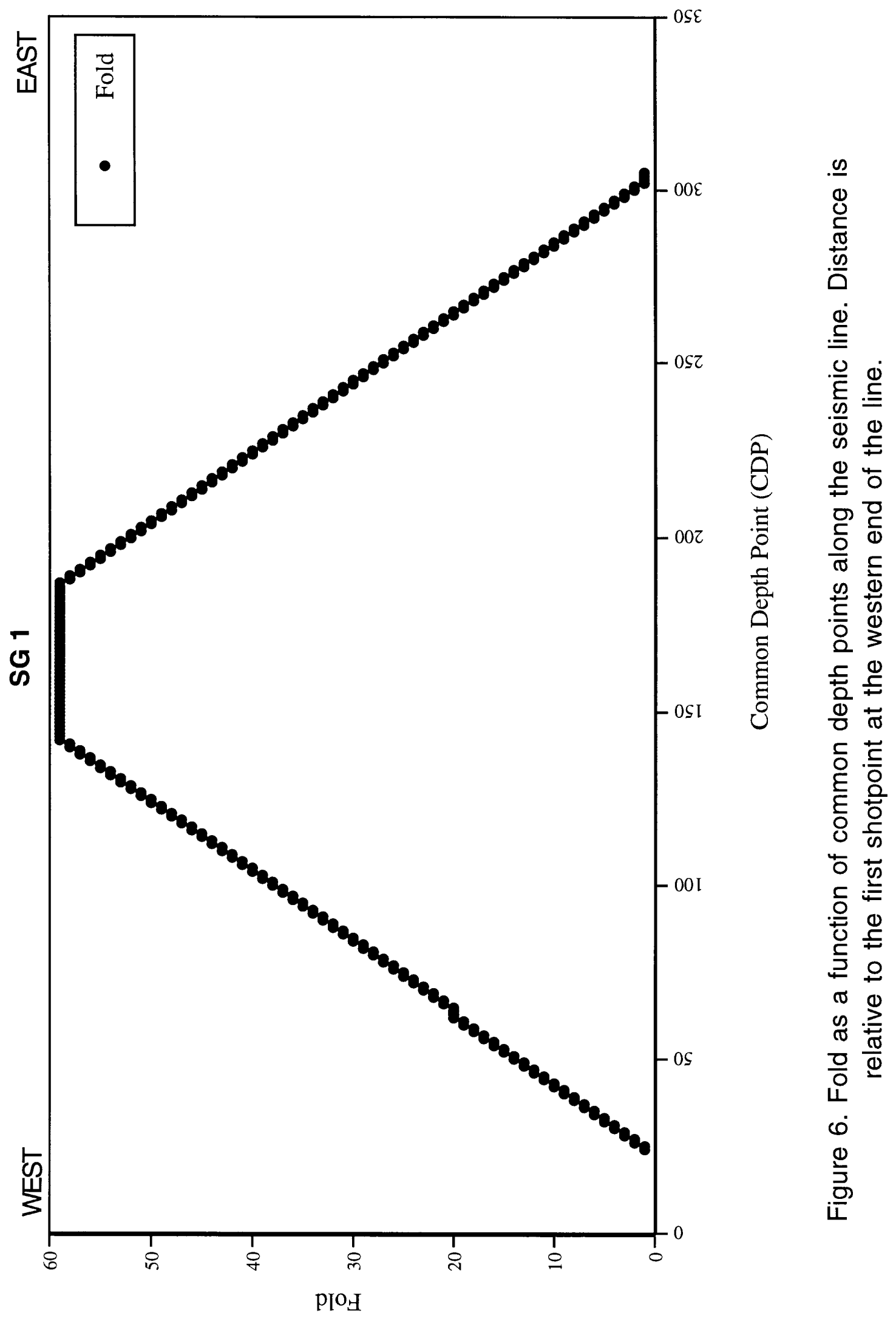


shot points that were not used because of cultural features (such as the I-10 freeway, utilities, etc).

Geophones varied in elevation by about $50 \mathrm{~m}$ along the seismic profile, with elevations increasing from south to north along the profile (Fig. 7). On seismic reflection sections, elevation is plotted relative to the topographically lowest geophone along the recording array, but reflections along the topographic variation were included in the seismic. reflection sections (e.g, topography above the datum was included with measured velocities). The geophone array varied from a straight line connecting the endpoints of the shot point array by a maximum of about $6 \mathrm{~m}$ (Fig. 8); thus, relative to the entire length of the seismic geophone array $(\sim 1300 \mathrm{~m})$, there was only about a $0.54 \%$ variation from a straight line. It is unlikely, therefore, that geometrical variations in the geophone array would generate artifacts in the data that could be interpreted as structure.

Profile SG 2 included shot points that extended beyond the ends of the geophone array. On the northern end of the seismic profile, additional shot points were placed north of the California Aqueduct. These additional shot points resulted in a slightly greater elevation variation of the shot-point array relative to the geophone array, with a maximum elevation variation in excess of $55 \mathrm{~m}$ (Fig. 9); thus, the maximum variation in shot point elevations were greater than those of the geophone array. Shot points north of the Colorado River aqueduct could not be placed in line with the rest of the shot point array due to cultural features. When those additional shot points are included, relative to a line connecting the endpoints of the shot point array, shot points varied by about $15 \mathrm{~m}$ (Fig. 10). In terms of percentage of the entire length of the shot-point array, the $15-\mathrm{m}$ variation in linearity is about $0.95 \%$, which is probably too little to cause artifact in stacked sections. However, there is about a $10 \mathrm{~m}$ change in the linearity of the shotpoint array over a distance of about $100 \mathrm{~m}$ north of the aqueduct. Such a large change could cause artifacts in the data. Therefore, caution must be used interpreting structures in that part of the seismic profile.

Fold along SG 2 varies linearly along most of the seismic profile, but there are variations at several locations, due largely to skipped shot points (Fig. 11). Maximum fold of 119 was obtained near the center of the seismic profile and decreased to about 1 near the ends of the profile. Maximum folds greater than 100 likely generates strong signals to depths in excess of several kilometers, and fold of about 1 may generate strong signals to depths in excess of $1 \mathrm{~km}$. 


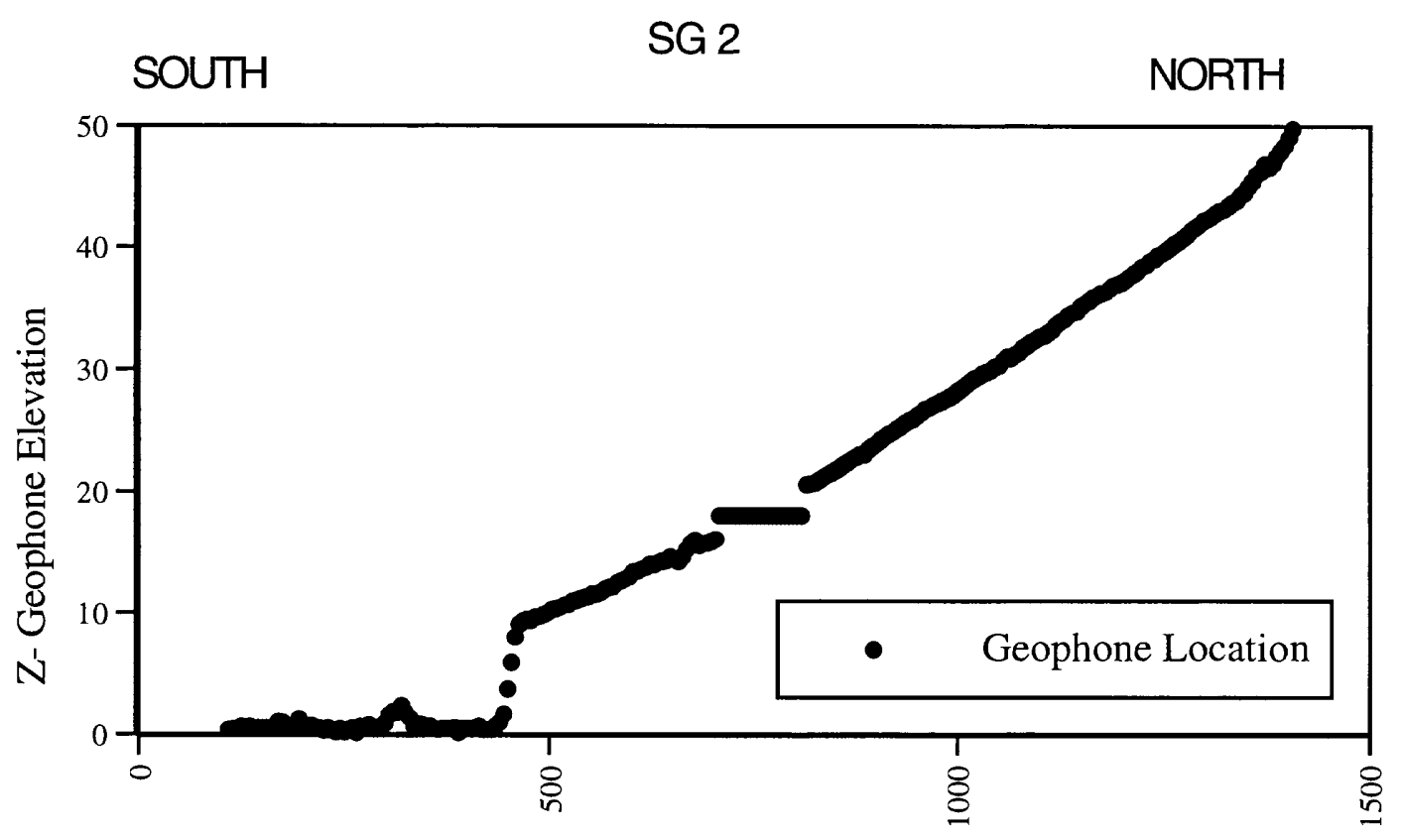

$\mathrm{X}$-Distance from first shotpoint $(\mathrm{m})$

Figure 7. Geophone elevation in SG 2. Elevation is relative to the topographically lowest shot point.

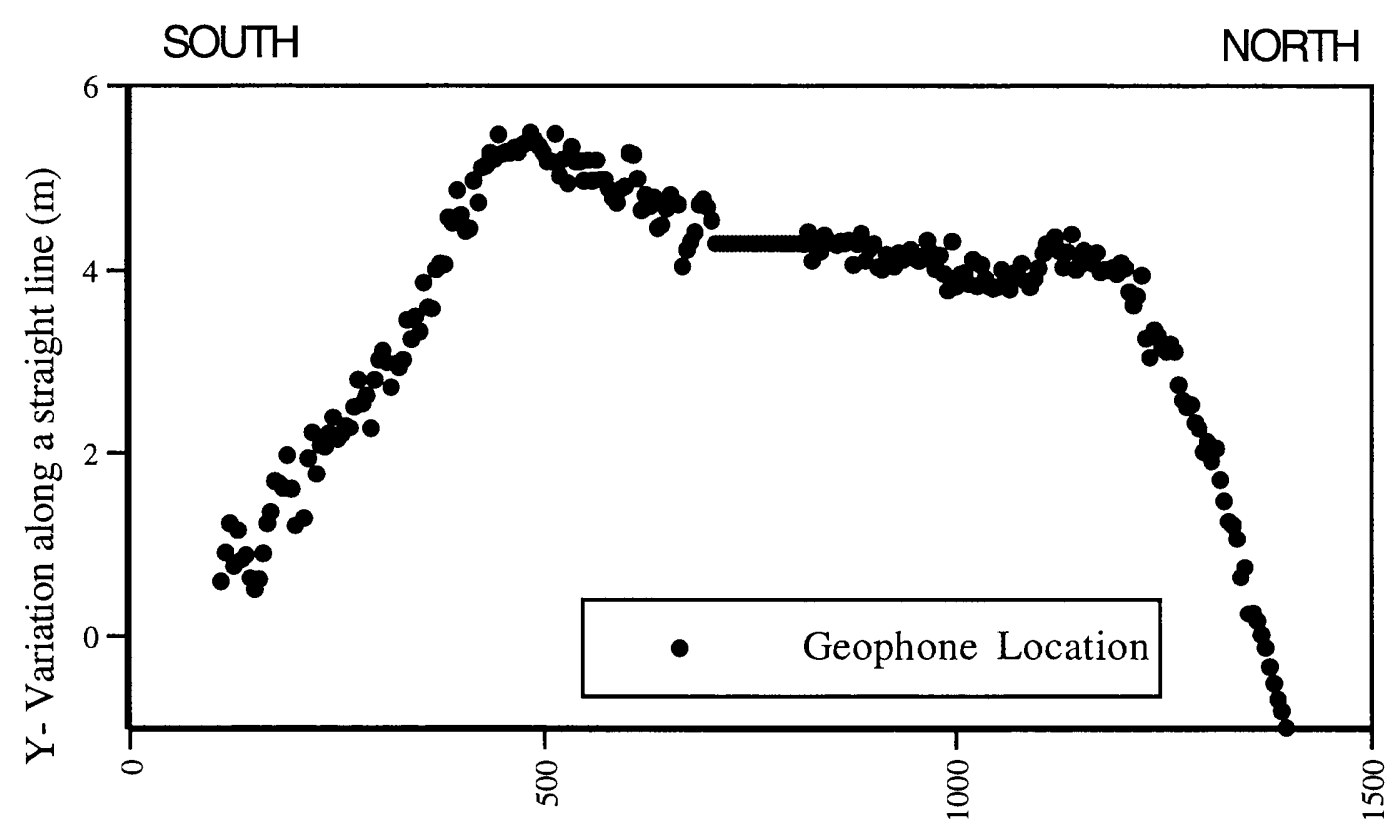

$\mathrm{X}$-Distance from first shotpoint $(\mathrm{m})$

Figure 8. Geophone variation from a straight line connecting the first and last shot point south of the Colorado River Aqueduct. 


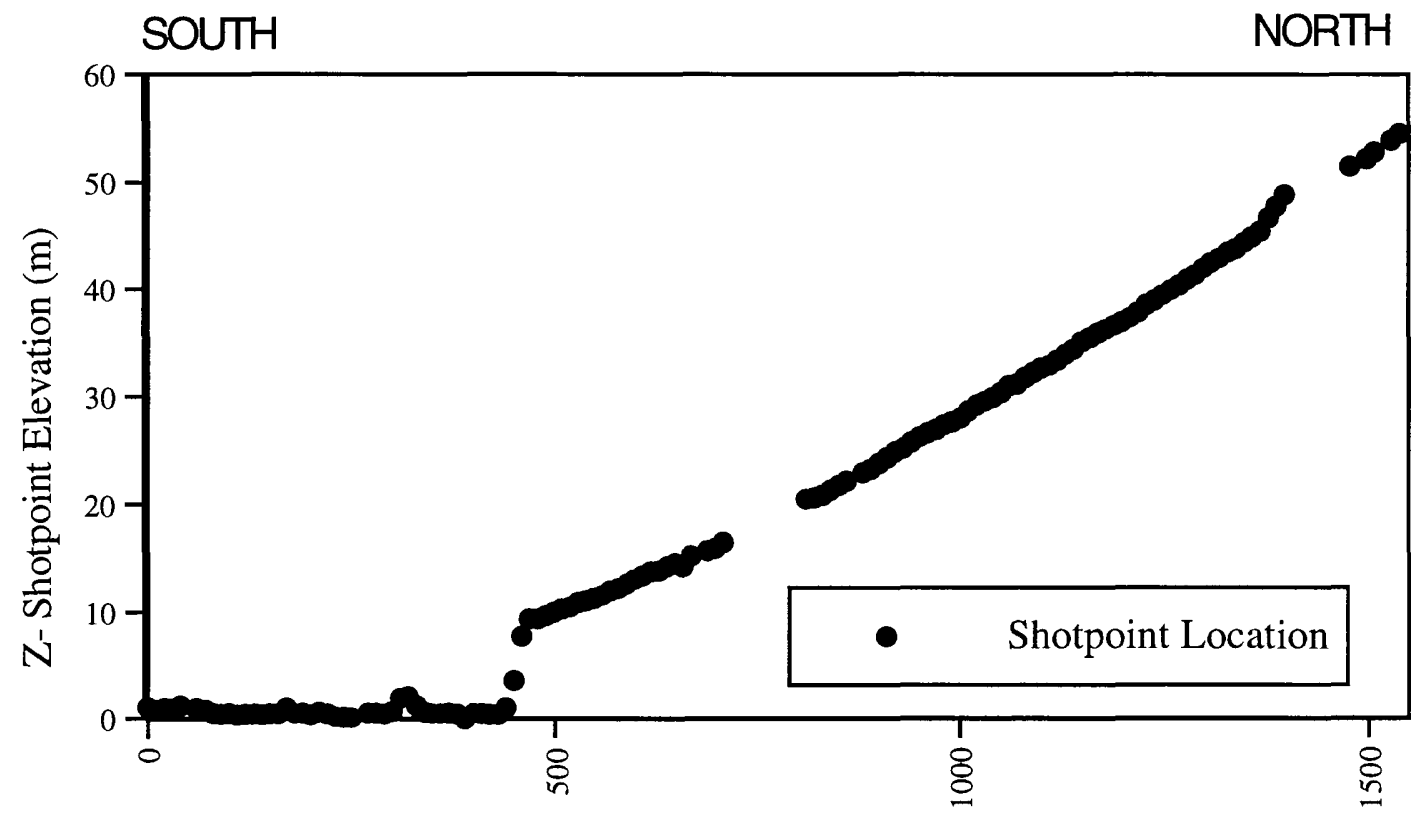

$\mathrm{X}$ - Distance from first shotpoint (m)

Figure 9. Shotpoint elevation along SG 2. Elevation is relative to the first shot point at the south end of the line.

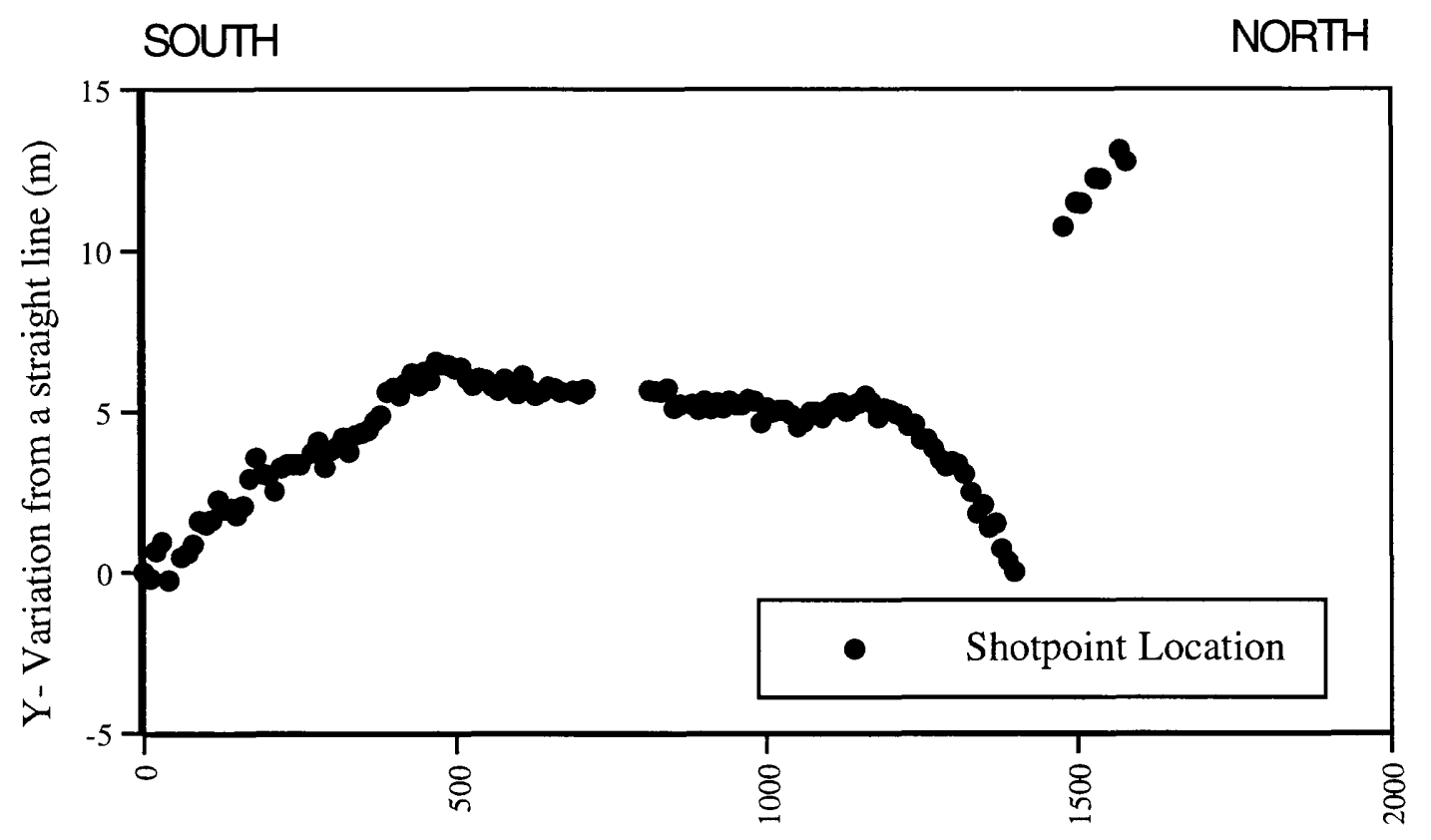

$\mathrm{X}$ - Distance from first shotpoint (m)

Figure 10. Shotpoint variation from a straight line connecting the first and last shotpoint south of the Colorado River Aqueduct. 


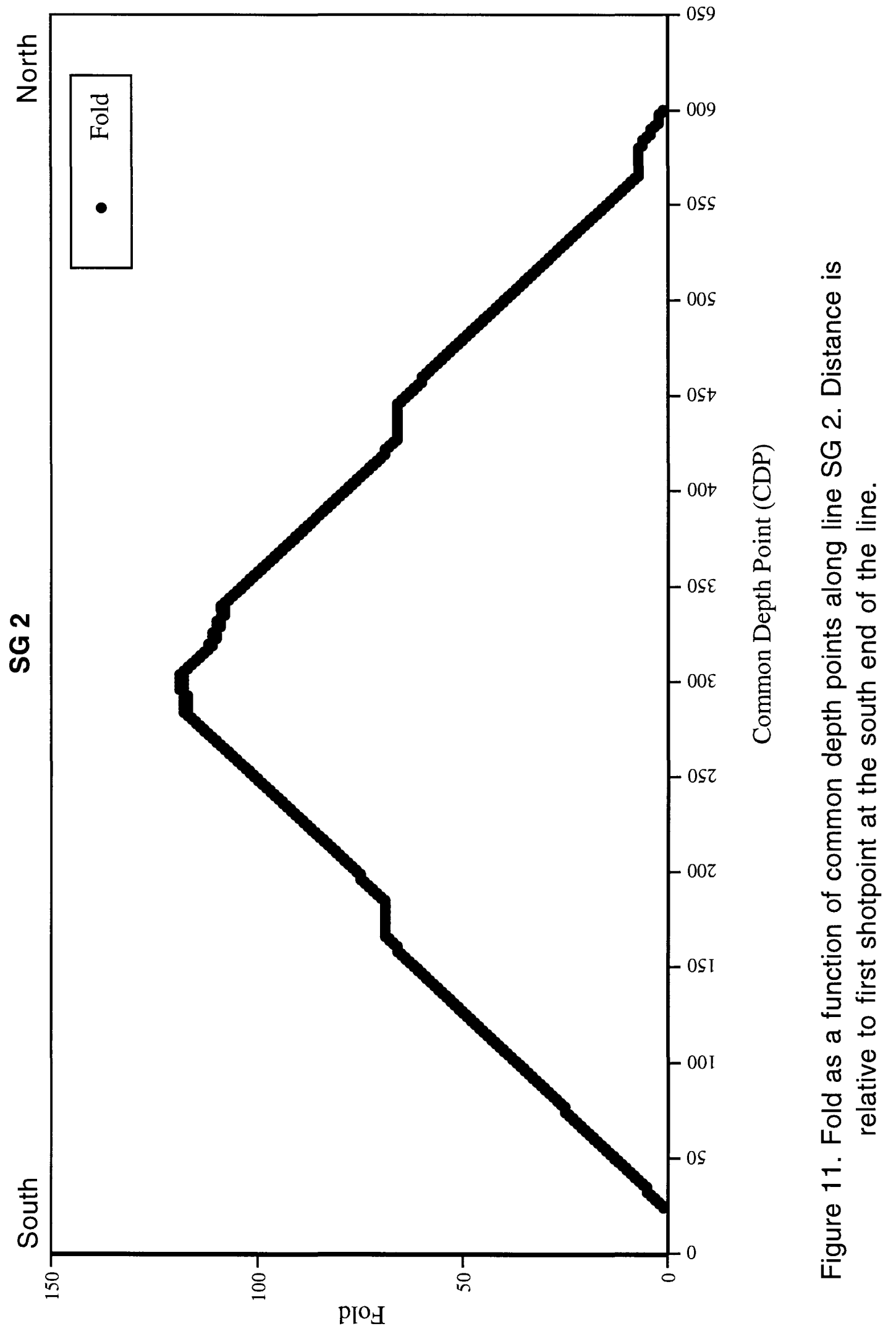




\section{Interpretation}

\section{Profile SG 1}

Interpreted Reflection Section

Migrated stacked seismic reflection images of the upper $1000 \mathrm{~m}(\sim 3200 \mathrm{ft})$ along

SG 1 are shown in figure 12. These data show numerous reflections from the near-surface to depths of approximately $1000 \mathrm{~m}$, however, reflections beneath about $400 \mathrm{~m}$ depth are probably associated with reverberation of the seismic signal near the crystalline rocksedimentary rock interface. Although there is lateral variation, in general, there are principal changes in the reflective character of the seismic section at depths of about $75 \mathrm{~m}$ and about 150-175 m, which are probably related to differences in lithology and/or physical properties of the subsurface at those depths. The seismic section above about $75 \mathrm{~m}$ probably corresponds to largely unconsolidated or poorly consolidated Quaternary sediments described by Allen (1957) (see Table 1). The lithology below the Quaternary sediments but above about $150 \mathrm{~m}$ depth is probably composed of Quaternary conglomerates, which Allen (1957) describes as ill-sorted conglomerates with clasts of crystalline rocks.

\section{Interpreted Refraction Section}

P-wave velocities range from about $800 \mathrm{~m} / \mathrm{s}$ at the surface to about $3500 \mathrm{~m} / \mathrm{s}$ at depths of about $225 \mathrm{~m}$ (Fig. 13). In the Cherry Valley area of the San Gorgonio Pass region, detailed seismic refraction measurements and well logs show that sediments with velocities of about $1500 \mathrm{~m} / \mathrm{s}$ correspond to the depth of the static water level (Catchings et. al, 1999; Gandhok et al., 1999). Based on the well log for well MS-25 (Christensen, pers. comm), the lithology of the San Gorgonio Pass region (Allen, 1957), and the velocities observed in this survey, P-wave velocities below about $1500 \mathrm{~m} / \mathrm{s}$ (at depths less than 200 $\mathrm{m}$ ) are interpreted to represent unconsolidated and unsaturated Quaternary sediments. Velocities between about $1500 \mathrm{~m} / \mathrm{s}$ and $3000 \mathrm{~m} / \mathrm{s}$ in that depth range probably represent compacted or poorly consolidated sediments that may be saturated or unsaturated, depending on whether the predominant composition is sand or clay. Velocities in excess of $3000 \mathrm{~m} / \mathrm{s}$ probably represent largely consolidated sediments (Mavko et al., 1996). Velocities representing fractured crystalline (metasedimentary) rocks of the San Gorgonio Pass region are likely to have velocities in excess of $4000 \mathrm{~m} / \mathrm{s}$, but our profile SG-1 was not long enough to obtain refractions from the depths needed to sample those velocities. 


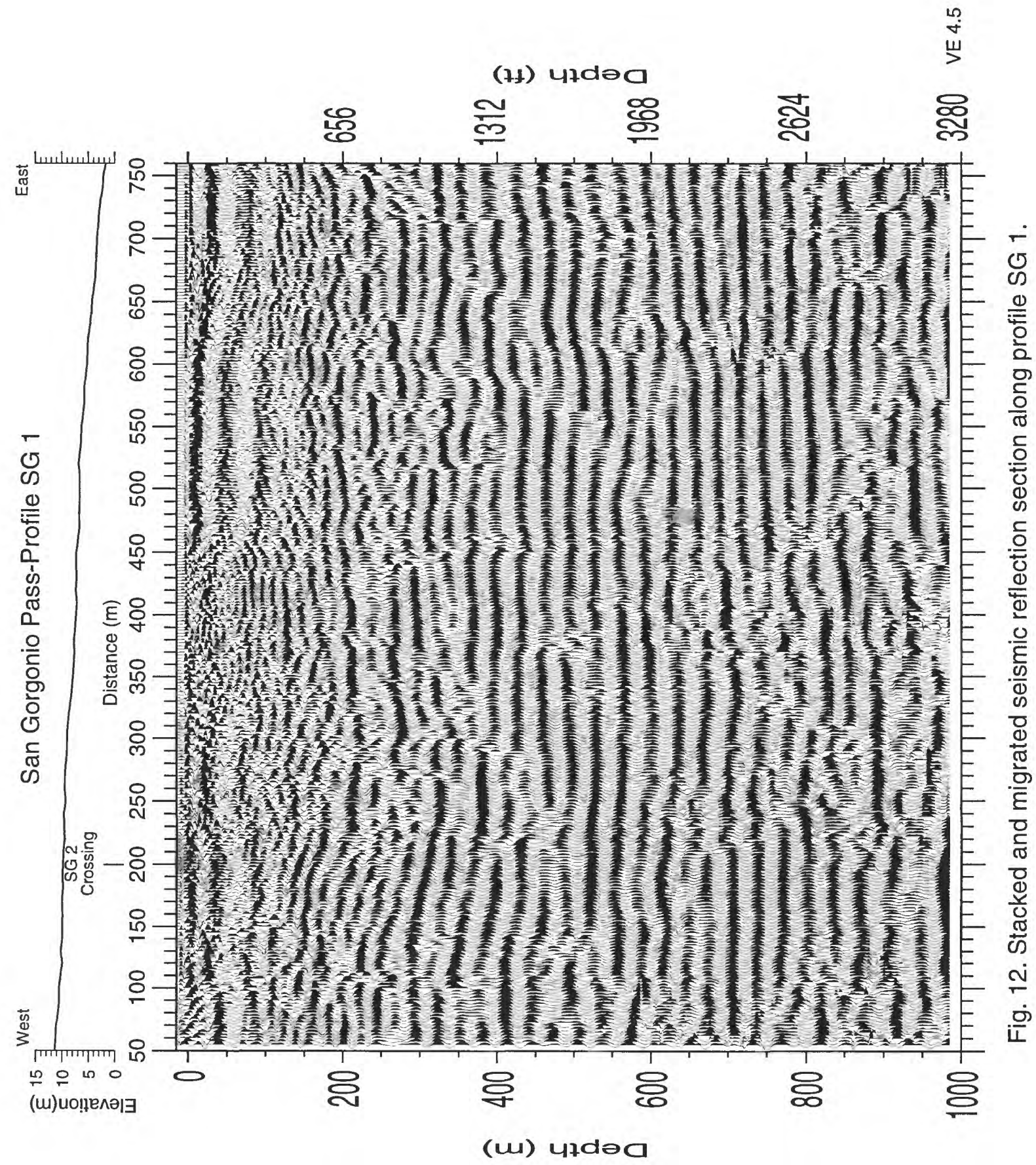




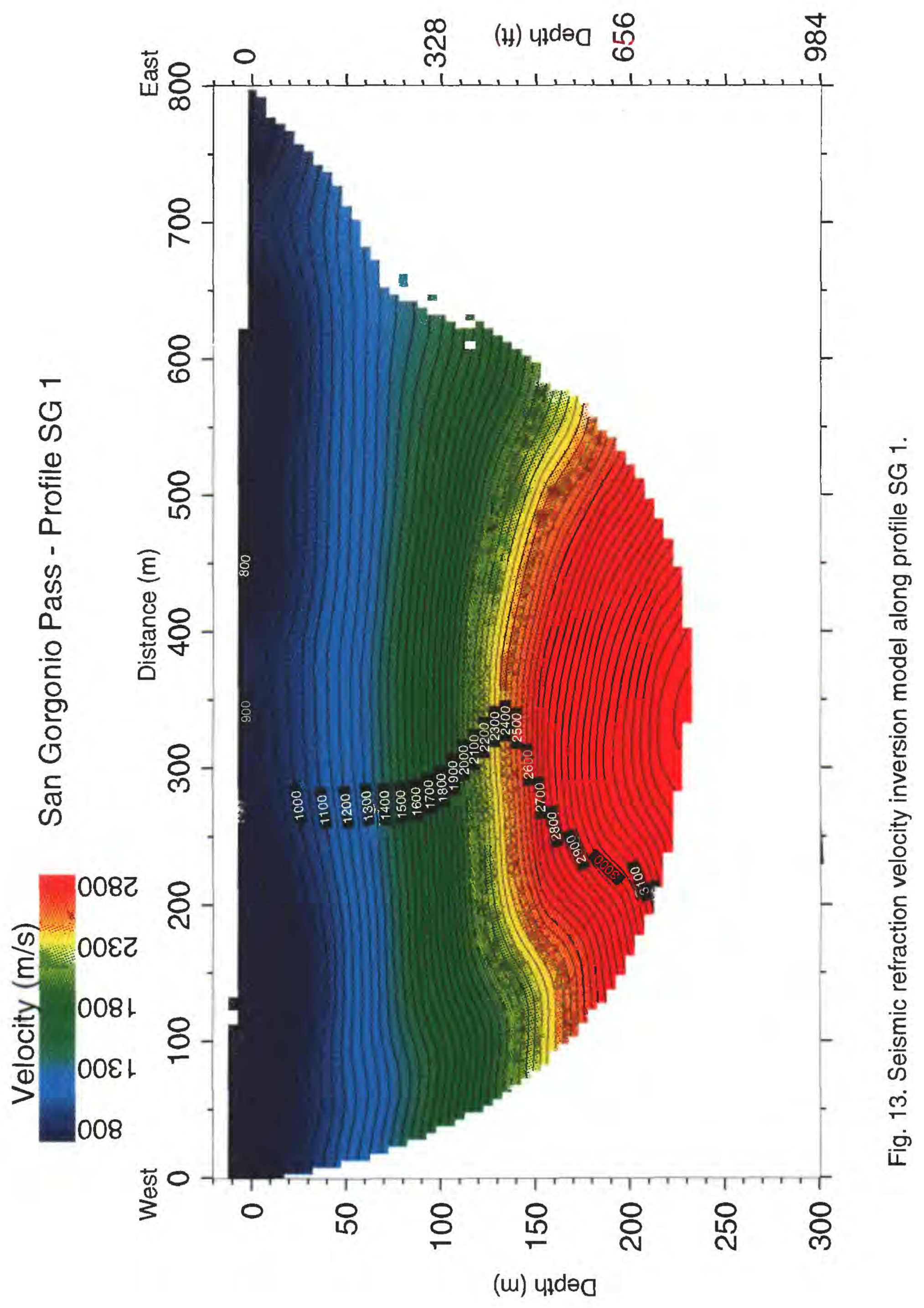




\section{Interpreted Combined Refraction/Reflection}

The combination of seismic velocities and seismic reflection images can be used to aid in interpreting the subsurface structure (Fig. 14a, 14b). Reflectors with velocities less than about $1500 \mathrm{~m} / \mathrm{s}$ extend to about $85 \mathrm{~m}$ depth and probably represent largely unsaturatec and unconsolidated sediments. This change in velocity coincides with a change in the reflection character, whereby, the reflectors apparently become more closely spaced. This depth range (below ground surface, bgs) is similar to that of the water level ( 82 to $86 \mathrm{~m}$; 268 to $281 \mathrm{ft}$ ) observed in well MS-25 on August 29, 1997. Well MS-25 is located about meter $10 \mathrm{~m}$ north of meter 262 on profile SG 1. (Note: distances along the seismic profiles are referred to as meter " $\mathrm{X}$ ", whereas depth is referred to as " $\mathrm{X}$ " $\mathrm{m}$.)

A more irregular reflection pattern occurs from about 85 to $200 \mathrm{~m}$ depth, and velocities in that depth range are between about $1500 \mathrm{~m} / \mathrm{s}$ and $3000 \mathrm{~m} / \mathrm{s}$. From about $85 \mathrm{~m}$ to about $200 \mathrm{~m}$ depth, the subsurface is probably dominated by saturated sediments (sands and clays) and poorly lithified rocks.

Reflections below about $200 \mathrm{~m}$ are more widely spaced and appear to become more reverbative with depth. Velocities in this depth range are between $3000 \mathrm{~m} / \mathrm{s}$ and $4000 \mathrm{~m} / \mathrm{s}$. Subsurface rocks in this range probably represent partially lithified sedimentary rocks or clays. Below about $300 \mathrm{~m}$ depth, the reflections are highly reverberative. In numerous other seismic imaging investigations, we have found that the reflections become reverberative for depths below the sediment/hard-rock interface. The reverberative nature, combined with the high velocity $(>3500 \mathrm{~m} / \mathrm{s})$ suggests that the rocks below about $300 \mathrm{~m}$ depth probably represent crystalline rocks, such as quartz monzonites observed in the San Bernardino Mountains to the north or metamorphic rocks observed to the south in the San Jacinto Mountains (Matti et al., 1992).

Generally, the pattern of reflections suggest that the unconsolidated and unsaturated sediments are thicker to the east, with maximum thickness approaching about $140 \mathrm{~m}$. Although there are limited velocity data to the east, velocities are consistent with thicker sediments and deeper crystalline rocks to the east. 


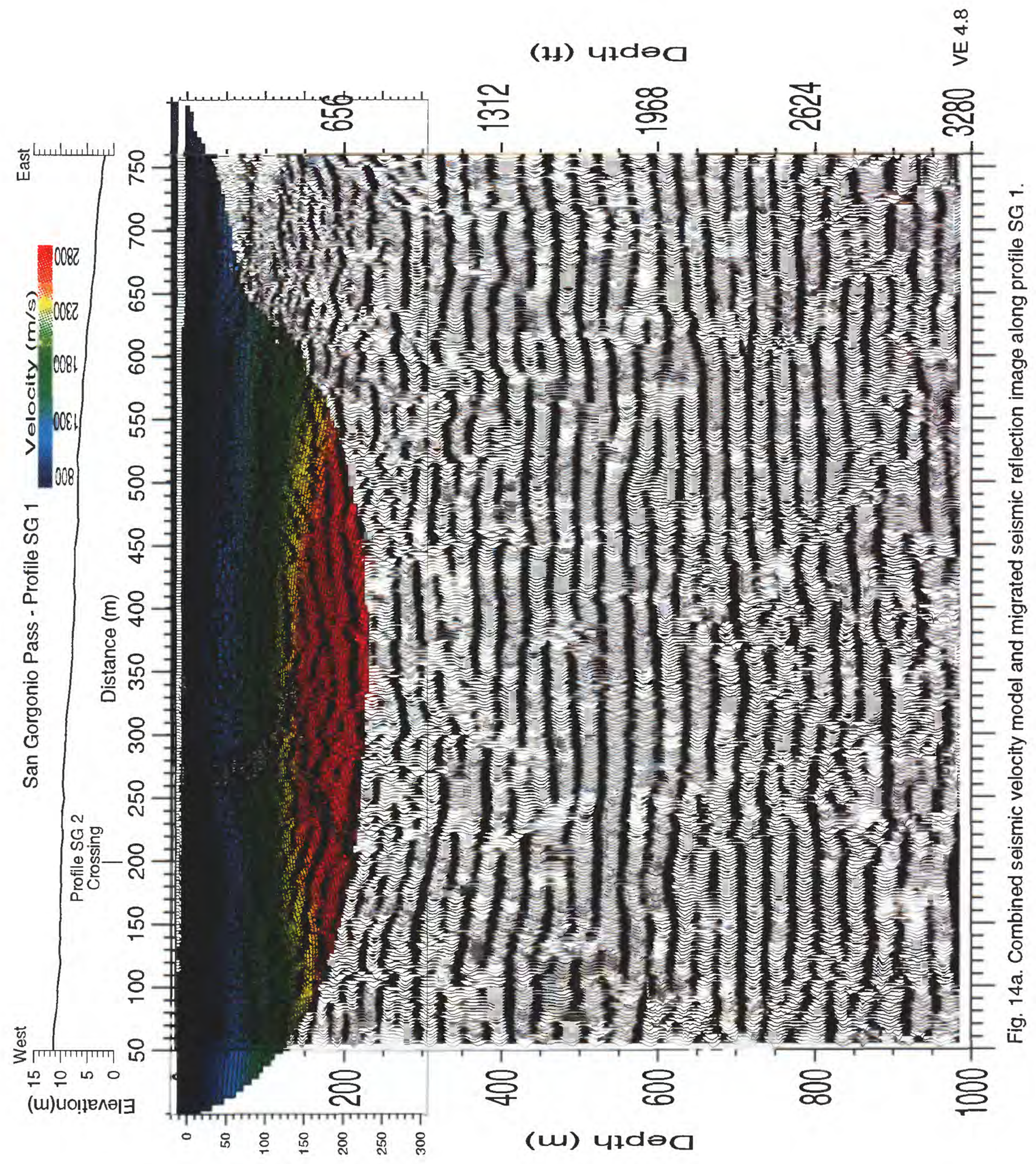




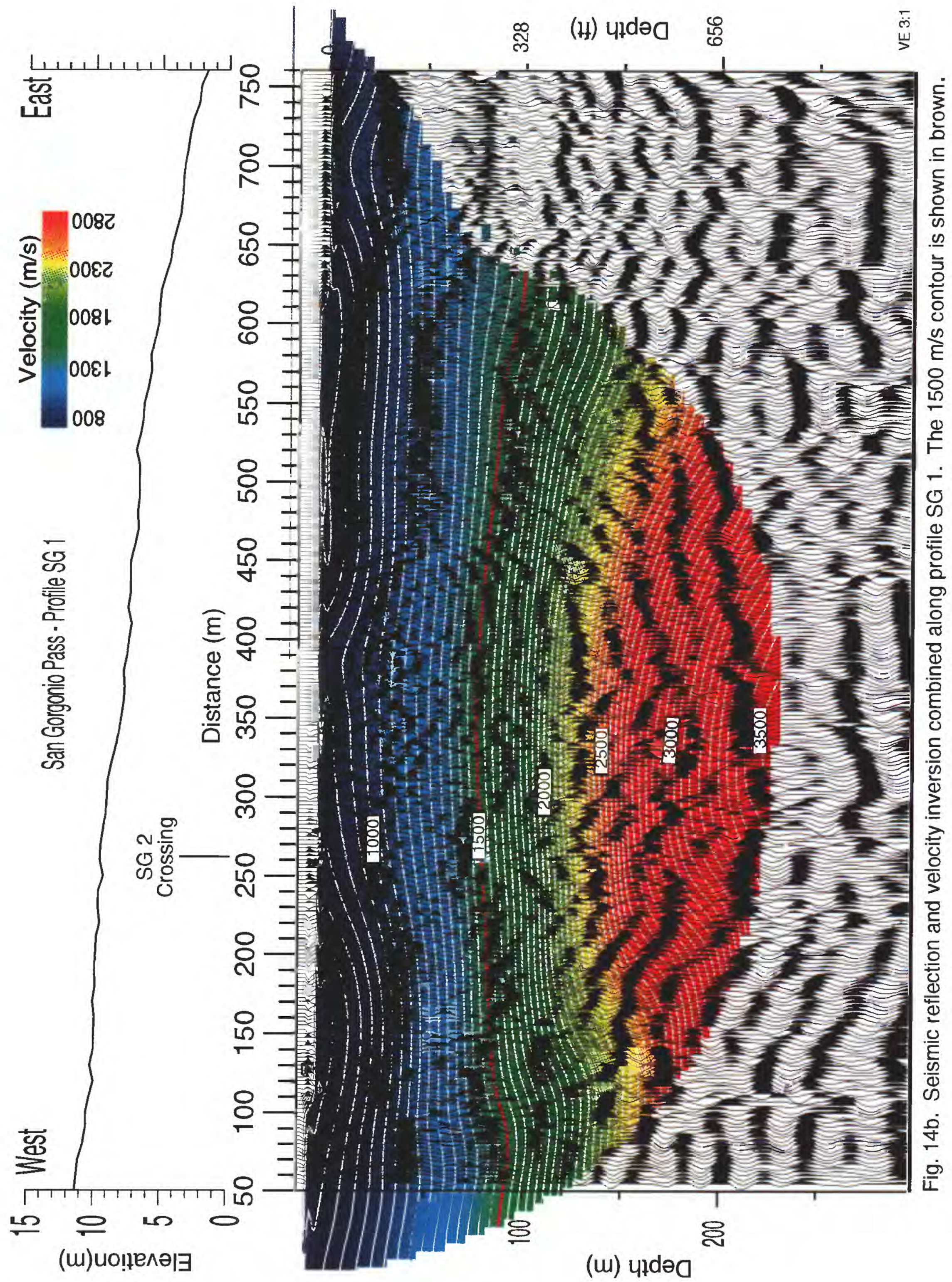




\section{Profile SG 2}

\section{Interpreted Reflection Section}

Unmigrated stacked seismic reflection images of the upper $1000 \mathrm{~m}(\sim 3300 \mathrm{ft})$ along SG 2 are shown in figure 15. These data show numerous reflections from the near-surface to depths of approximately $300 \mathrm{~m}$. Below about $300 \mathrm{~m}$ depth, the seismic section show strong reverberations that may result from reverberation of the seismic signal near the crystalline rock-sedimentary rock interface. There are large lateral variations in the seismic section from south to north. In the south, from about meters 0-450 distance, within the San Gorgonio River, the upper $\sim 50 \mathrm{~m}$ (depth) of the subsurface is characterized by a welllayered, largely planar sequence of sediments. From about meters 500 to about meter 1000 distance, this sequence of sediments is thickest and less well layered. Northward of meter 1000 , the well-layered sequence appears to thin and eventually pinch out.

In the depth range from about 50 to $100 \mathrm{~m}$, the sedimentary sequence appears to be much less planar and irregular (Fig. 16). Abrupt offsets and diffracted sesimic energy suggest that the subsurface may be highly faulted at this depth. Higher-frequency diffractions are observed along most of the length of the profile below about $100 \mathrm{~m}$ depth. These high-frequency diffractions may arise from irregular surfaces such as large boulders or faults. A series of faults are apparent from the southern end of the profile to about meter 600 ; however, between meters 400 and 500, there appears to be an intense zone of faulting. This intense zone of faulting may be responsible for the strong, low-frequency apparent reflections from depths in excess of $300 \mathrm{~m}$ to about $1200 \mathrm{~m}$ in the distance ranges from about $550 \mathrm{~m}$ to about $1000 \mathrm{~m}$. These apparent reflections suggest a northward dip of strata; however, due to the complexity of the structure observed and the number of diffractions observed on the section, it is likely that these apparent reflections do not represent the true structure. We used migration techniques to collapse diffractions and to move the reflected seismic energy to its proper location on the reflection section.

Migrated stacked seismic reflection sections of the upper $1000 \mathrm{~m}$ of profile SG 2 are shown in figure 16. The frequency content of the migrated section does not permit detailed resolution of the shallow sediments above $100 \mathrm{~m}$ depth, but structure below about $100 \mathrm{~m}$ is better characterized. These sections show that the strong, low-frequency, northdipping reflections near the center of the seismic profile are actually south-dipping reflections that originate in the upper $300 \mathrm{~m}$. 


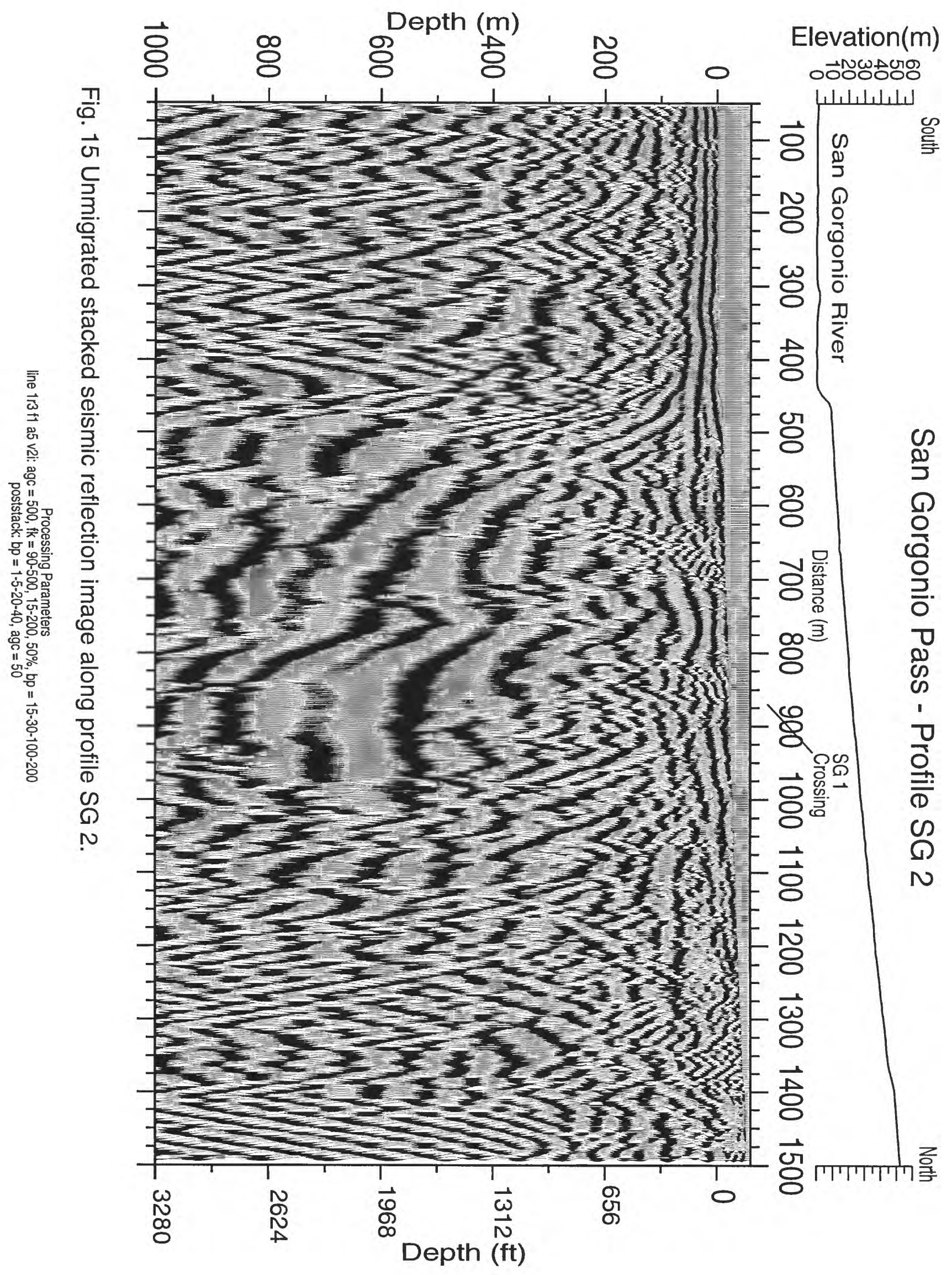




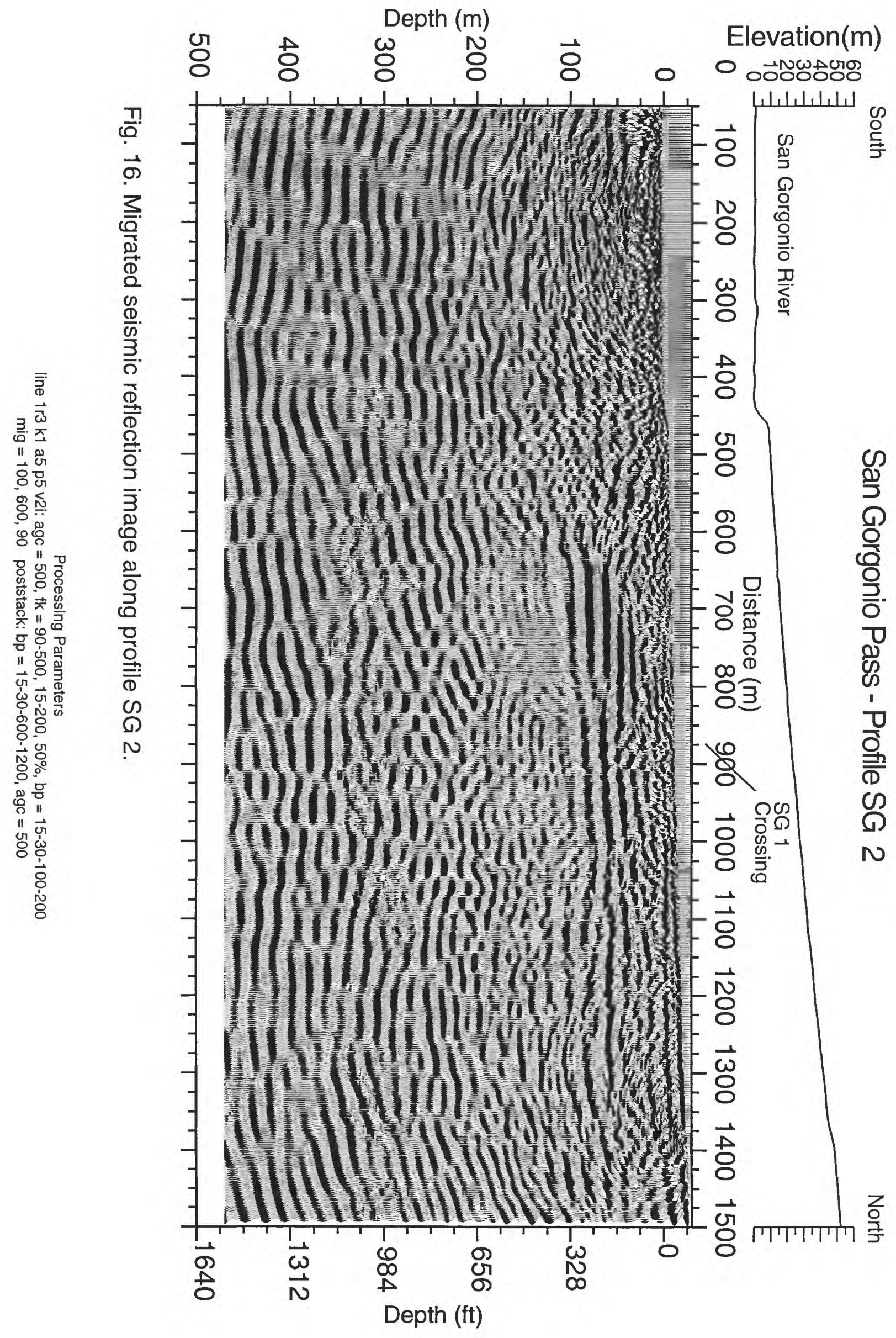


Interpreted Refraction Section

P-wave velocities range from about $700 \mathrm{~m} / \mathrm{s}$ at the surface to about $4000 \mathrm{~m} / \mathrm{s}$ at depths of about $350 \mathrm{~m}$ (Fig. 17). The velocities and interpretations are comparable to those described in the section on SG 1. Velocities that are less than $1500 \mathrm{~m} / \mathrm{s}$ at depths of about $100 \mathrm{~m}$ likely represent unconsolidated and unsaturated Quaternary sediments. These sediments appear to be thicker in the southern part of the section. Velocities between the values of $3000-4000 \mathrm{~m} / \mathrm{s}$ probably represent consolidated rock (Mavko et al, 1996), and velocities greater than $4000 \mathrm{~m} / \mathrm{s}$ likely represent consolidated rock.

\section{Interpreted Combined Refraction/Reflection}

The superposition of the velocity data on the reflection data for SG 2 also aids in interpreting the subsurface (Fig. 18a and 18b). The combined section shows that there is a general southward dip in structure toward the San Jacinto Mountains. The shallow, unconsolidated and unsaturated sediments are best seen on the unmigrated sections, but the velocity data show velocities less than about $1500 \mathrm{~m} / \mathrm{s}$ that extend to depths of $85 \mathrm{~m}$ beneath meter 900 (where SG 1 crosses SG 2). These sediments apparently thicken to the south, where they are about $120 \mathrm{~m}$ thick at the southernmost end of the profile. The underlying, more consolidated sediments also dip to the south from the northern end of the profile to about meter 700 . From about meter 700 to meter 0 , the strata with velocities ranging from about $1500 \mathrm{~m} / \mathrm{s}$ to about $3000 \mathrm{~m} / \mathrm{s}$ appear to be folded and faulted in the upper $150 \mathrm{~m}$ and have northerly as well as southerly dips (Fig. 18b). The thickness of this strata increases from about $150 \mathrm{~m}$ at meter 900 to nearly $250 \mathrm{~m}$ toward the southern end of the profile. Crystalline rocks $(>4000 \mathrm{~m} / \mathrm{s}$ ) also deepen from the north to the south.

\section{Discussion and Conclusions}

\section{Stratigraphic Horizons:}

One of the principal objectives of this study was to map the basic stratigraphic horizons, including the depth to the base of the unconsolidated sediments and the depth to the top of crystalline rock. If the stratigraphic depths were known in a particular location from well logs, the seismic images and velocities could be used to laterally map the stratigraphy based on correlation with the well logs. However, the only well in the immediate vicinity of the seismic profiles was Well MS-25, which at $142 \mathrm{~m}(465 \mathrm{ft})$ depth did not reach crystalline rock and may not have reached the base of the unconsolidated sediments. The well log, described as "sand, gravel, and boulders to a depth of $465 \mathrm{ft}$ " did not provide much detail about the stratigraphy. Although the stratigraphy is not well 


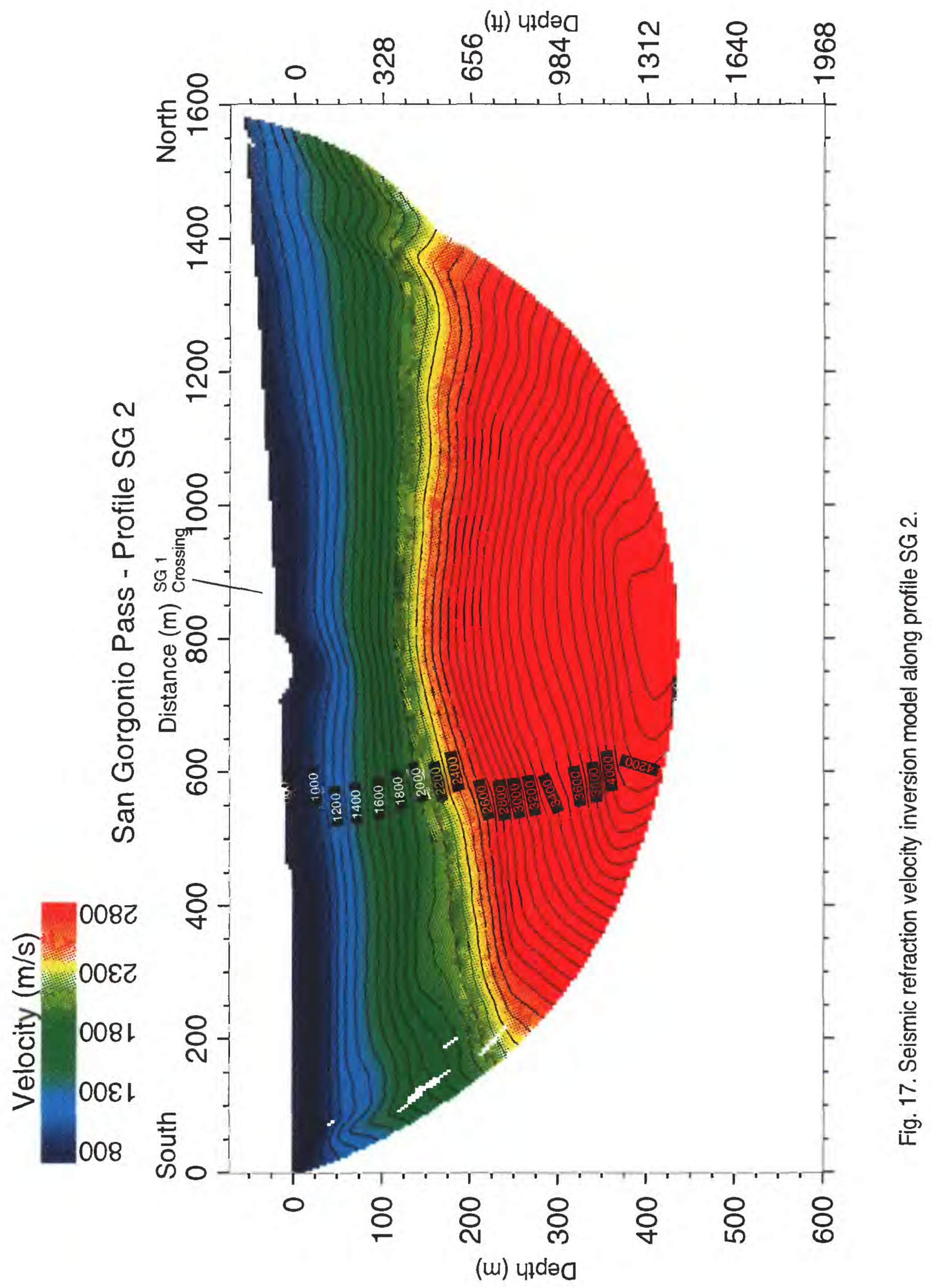




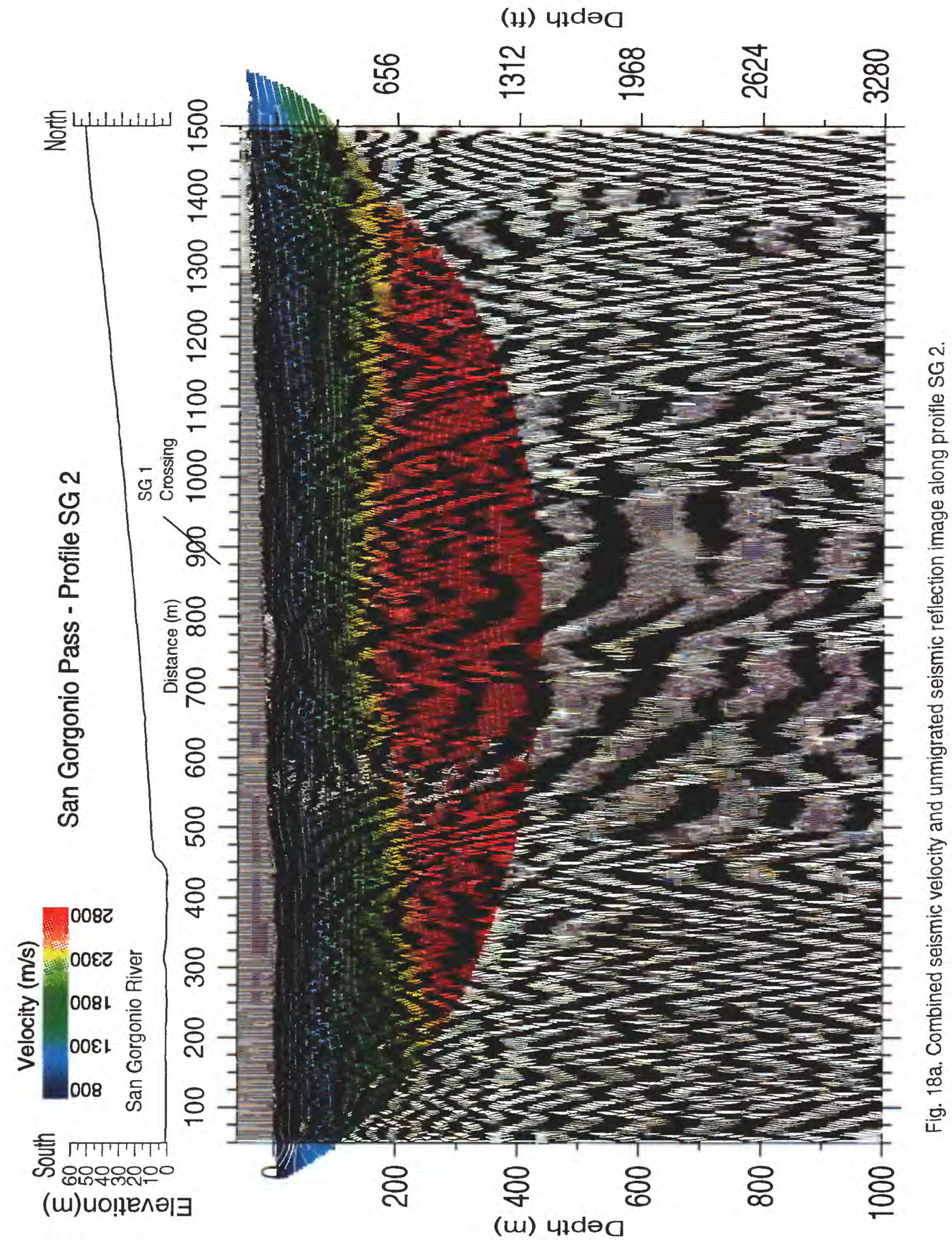




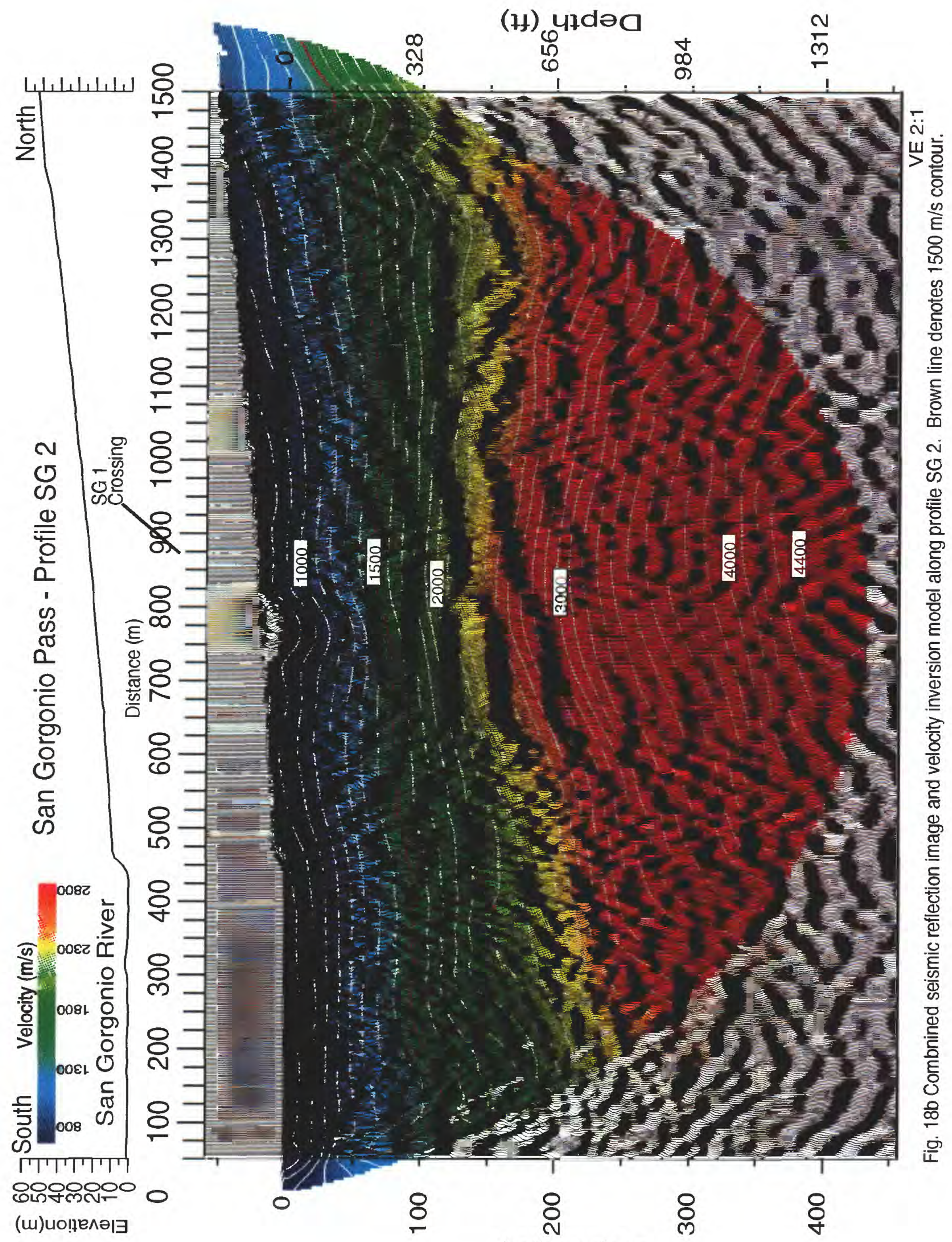

(ii) yłdəa 
determined from the MS-25 well-log, that well log, combined with seismic velocity and seismic reflection images, can be used to provide considerable constraints on the stratigraphy. A number of factors other than composition can influence the seismic velocit:r of subsurface strata, including depth of burial (pressure), how well lithified the sediments are, degree of water saturation, degree of faulting and fracturing, etc., but most lithified sedimentary rocks are likely to have compressional velocities (Vp) greater than about 2500 $\mathrm{m} / \mathrm{s}$. For example, from laboratory experiments, Nur (1982) shows Berea and Massilon sandstones (both highly porous sandstones) have miminum compressional velocities of about $3100 \mathrm{~m} / \mathrm{s}$ and $2800 \mathrm{~m} / \mathrm{s}$, respectively, at 0 effective pressure (atmospheric pressure = pressure at the surface). These rocks have much higher velocities at higher pressures (greater burial depths), but if we adopt the minimum velocity of $2800 \mathrm{~m} / \mathrm{s}$ as the velocity of lithified sediments in San Gorgonio Pass, the minimum depth of lithified sediments $(\mathrm{Vp}=2800 \mathrm{~m} / \mathrm{s}$ ) would range from about $160 \mathrm{~m}$ to more than $200 \mathrm{~m}$ along profile $\mathrm{SG} 1$ (Fig. 13). Considering both the velocity data and the reflection data, it is likely that a strong reflection and a change in the reflection pattern at about $200 \mathrm{~m}$ depth represent the base of unconsolidated sediments and the top of consolidated sediments ( $\mathrm{Vp}=3300 \mathrm{~m} / \mathrm{s}$ ). Along profile SG 2, the depth to the $2800 \mathrm{~m} / \mathrm{s}$ contour is greater than about $250 \mathrm{~m}$, suggesting that unconsolidated sediments extend to that depth near the northern end of the San Jacinto mountains. These unconsolidated sediments appear to thin to about $200 \mathrm{~m}$ total thickness beneath the I-10 freeway, but appear to thicken to about $280 \mathrm{~m}$ near the north end of the profile. The apparent thickening to the north and south may be due to a increased sedimentation near each mountain range.

For both Berea and Massilon sandstones, velocities at pressures of up to 800 bars (depths of $\sim 2 \mathrm{~km}$ ) are about $4100 \mathrm{~m} / \mathrm{s}$ and $3800 \mathrm{~m} / \mathrm{s}$, respectively (Nur, 1982). For the illsorted conglomerates and sandstones that should underly San Gorgonio Pass at shallower depths (Allen, 1957), we should expect similar velocities. If we assume the $\sim 4000 \mathrm{~m} / \mathrm{s}$ velocity to approximate the base to the consolidated sedimentary rocks, then the mimimum depth to crystalline basement rocks should be at about $350 \mathrm{~m}$ along profile $\mathrm{SG} 2$, increasing to the south. A change in the reflection pattern, even though it is reverberative, also occurs at this depth near the center of the profile.

\section{Water Level}

Because the velocity of seismic compressional waves in water is approximately $1500 \mathrm{~m} / \mathrm{s}$, and the velocity of compressional waves in unconsolidated sediments is approximately the same (Schon, 1996), we can use the detailed velocity measurements to laterally map the water level along profiles SG1 and SG 2 . The depth to the water level in 
Well MS-25 (located at about meter 262 on SG 1 and meter 875 on SG 2) was determined to be between $82 \mathrm{~m}(268 \mathrm{ft})$ and $86 \mathrm{~m}(281 \mathrm{ft})$ on August 29,1997 . The $1500 \mathrm{~m} / \mathrm{s}$ velocity contour on both profiles near Well MS-25 is about $85 \mathrm{~m}$, consistent with the depth found in the well. Toward the southern end of profile SG 2, near the San Jacinto mountains, the $1500 \mathrm{~m} / \mathrm{s}$ contour (and presumably the water level) increases in depth to about $115 \mathrm{~m}$ to $120 \mathrm{~m}$. Near the very ends of the seismic profiles, the velocity contours may experience edge effects, but near the northern end of profile SG 2, the depth to the water level apparently decreases to about $75 \mathrm{~m}$. Along profile SG 1, the apparent water level $(1500 \mathrm{~m} / \mathrm{s}$ contour) appears to increase slightly (to about $90 \mathrm{~m}$ depth) to the east (at meter 600), but we do not have velocity data near the eastern end of the profile at the depths needed to map the $1500 \mathrm{~m} / \mathrm{s}$ coutour. In general, the water table appears not to vary greatly $(\sim 5 \mathrm{~m})$ from east to west along the profiles, but it does vary appreciably $(\sim 30 \mathrm{~m})$ from north to south.

\section{Faults:}

Faulting in the San Gorgonio Pass region is known to be highly complex (Matti et al., 1992), and our interpretation of faulting (Figs. 19 and 20) on the seismic sections is consistent with the complexities observed by surface mapping (Matti et al., 1992). Along profile SG 1, there appear to be smaller near-vertical faults along much of the section and more pronounced faults appear to be located toward the eastern end of the profile, surfacing near meters 610 and 690 (Fig. 19). Along much of the profile, the cummulative effect of the smaller faults appears to have vertically offset layers in the upper $100 \mathrm{~m}$ by as much as $25 \mathrm{~m}$. Near the central and western end of SG 1, there appear to be a series of apparent small horst and graben structures, with each horst or graben being less than about $100 \mathrm{~m}$ wide. Near the western end of profile SG 1, there appear to be minor folding of strata between $100 \mathrm{~m}$ and $300 \mathrm{~m}$ depth, with the apex of the fold to the west. Due to its limited length and apparent semi-parrallelism with regional fault systems, faulting and folding relationships are difficult to understand along profile SG 1 and will have to be combined with surface mapping and other seismic investigations to fully understand them.

Profile SG 2 trends largely perpendicular to the regional fault systems and is about twice the length of profile SG 1, allowing better images of apparent faults and folds (Fig. $20)$. In the northern half of profile SG 2 , there appear to be several high-angle $\left(\sim 65^{\circ}\right.$ to $70^{\circ}$ ), north-dipping faults that may have offset strata by less than about 10 to $20 \mathrm{~m}$. Toward the center of the profile, however, high-angle faults appear to be south-dipping along the north limb of an apparent fold. There appear to be two folds in the upper $100 \mathrm{~m}$ along the southern half of profile SG 2 that seem to be related to one or more north-dipping thrust faults. These apparent thrust faults appear to surface south of the southern end of 


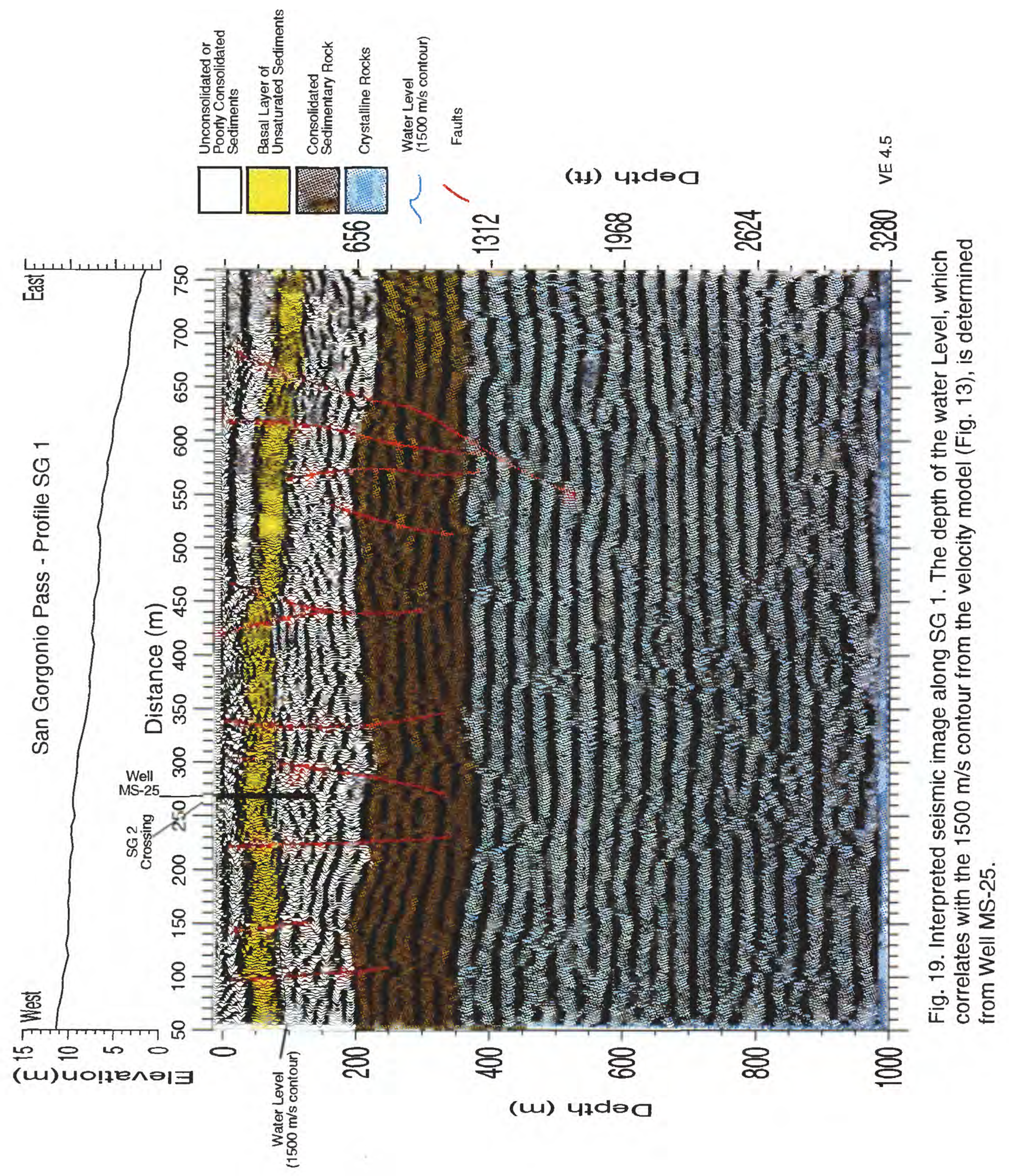




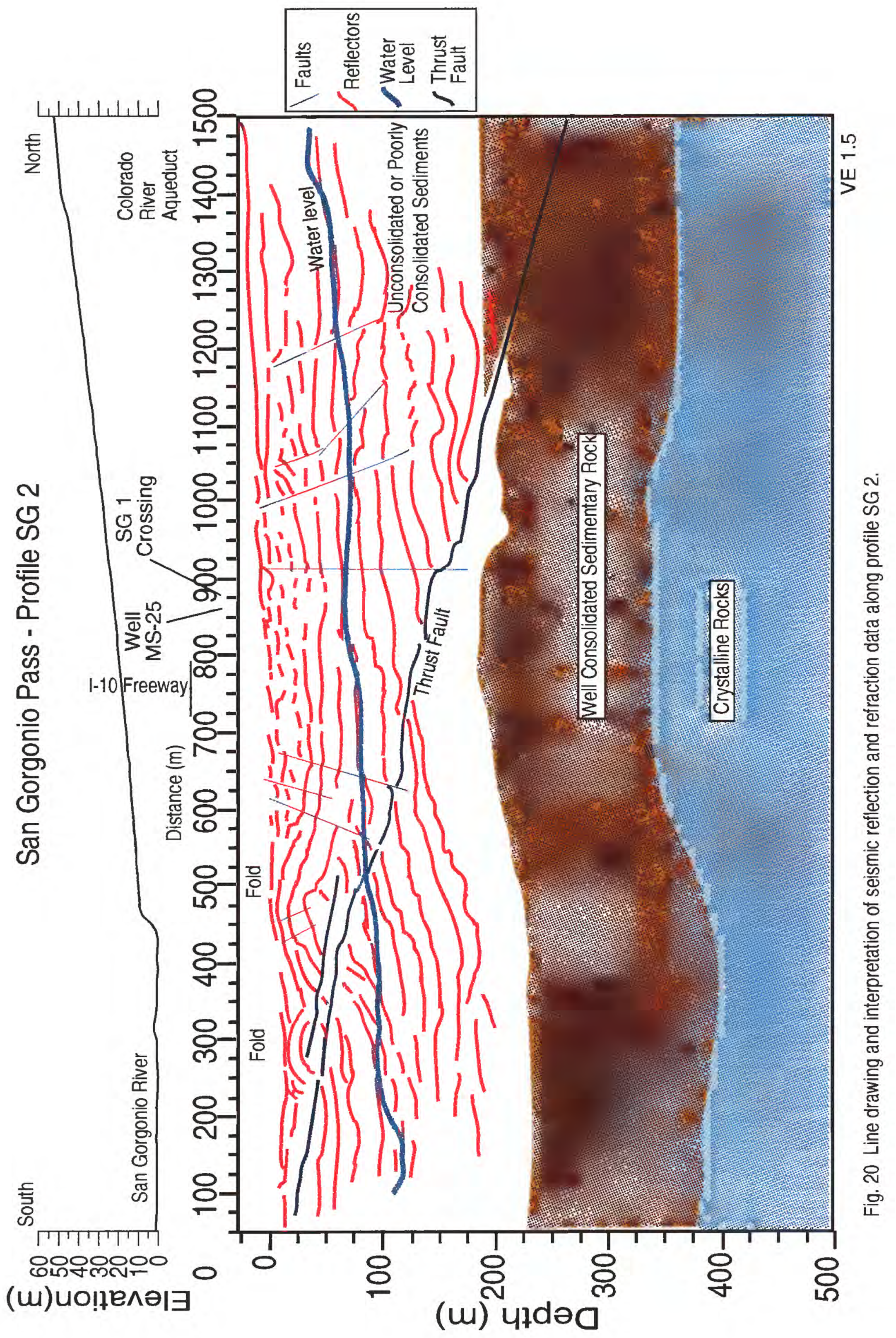


profile SG 2 and dip northward between $10^{\circ}$ and $15^{\circ}$ across profile SG 2 in the upper few hundred meters. As interpreted, the apparent thrust fault is located within the unconsolidated sediments and sedimentary rocks (above crystalline basement) along the entire profile.

We acknowledge that the apparent folds and faults along profile SG 2 can be interpreted differently, but we have chosen this interpretation because it appears to fit the seismic image and it explains other observations in the data. For example, a north-dipping thrust fault better explains the presence of low-frequency, north-dipping reflectors that are observed on the unmigrated seismic sections (between $200 \mathrm{~m}$ and $1000 \mathrm{~m}$ depth) near the center of profile SG 2, and the folds account for the north- and south-dipping reflections above $200 \mathrm{~m}$ depth on the southern half of the profile SG 2 (Fig. 15). Furthermore, the velocity model for profile SG 2 shows that velocities greater than about $2500 \mathrm{~m} / \mathrm{s}$ increase in dip southward near the center of the seismic profile which is consistent with the expectation of thicker sediments as a result of thrusting to the south.

\section{Implication for Water Resources:}

The seismic data suggests that the upper $200 \mathrm{~m}$ of the subsurface along profile SG 1 consists largely of unconsolidated sediments. The water level $(1500 \mathrm{~m} / \mathrm{s})$ appears to range from about $85 \mathrm{~m}$ to $90 \mathrm{~m}$ below the ground surface, with a slight increase in depth to the east (Fig. 14b). There is apparent faulting along most of the seismic profile (Fig. 19), but the smaller faults do not appear to affect the depth of the $1500 \mathrm{~m} / \mathrm{s}$ contour (water level). However, because the velocity model has been laterally and vertically smoothed (5$\mathrm{m}$ smoothing), the 1500-m/s contour may not accurately reflect small changes in the depth to the water level. If the reflection that correlates with the $1500-\mathrm{m} / \mathrm{s}$ contour arises from the water table (Fig. 14b), then this reflection suggests that the water table rises and deepens laterally across the faults by several meters. However, the more prominent faults near the eastern end of the array suggests that the water table is affected by faults to a greater extent, as the water table $(1500 \mathrm{~m} / \mathrm{s}$ contour and reflector) appears to deepen to the east.

The predominant water-bearing strata is probably between about $85 \mathrm{~m}$ and $200 \mathrm{~m}$ depth because velocities beneath $200 \mathrm{~m}$ depth are sufficiently high that it is unlikely that the rocks are porous at that depth. It is possible that these rocks are highly fractured, which in theory, could significantly increase the secondary permeability. However, cements in non crystalline (sedimentary) rocks typically limit the fracture permeability, suggesting that they are probably not very permeable below about $200 \mathrm{~m}$ depth. The seismic data suggest that the water-bearing strata is probably from about (relative to ground surface) $120 \mathrm{~m}$ to about $250 \mathrm{~m}$ deep ( $130 \mathrm{~m}$ thick) near the southern end of profile SG 2 and is about $75 \mathrm{~m}$ to 
about $250 \mathrm{~m}$ deep ( $175 \mathrm{~m}$ thick) near the northern end. The depth to the top of the water level appears to decrease slightly to the south across the apparent thrust fault.

These observations suggest that the water table varies laterally in both east-west and north-south directions, with the greatest variation from north to south. The lateral variations are due to large-scale structure, such as basin structure, and to smaller scale structures, such as faults. Lateral flow across faults is probably inhibited by the structure of the faults, an important consideration with respect to groundwater flow modeling and water storage.

Correlations with existing well data, along these profiles and at other locations within San Gorgonio Pass, indicate that these seismic methods are ideal for mapping the water table and its lateral variations.

\section{Implications for Earthquake Hazards:}

The seismic data, combined with exisiting surface mapping (Matti et al., 1992) suggest that San Gorgonio Pass is underlain by numerous high-angle $\left(>60^{\circ}\right)$ faults and more than one low-angle $\left(\sim 15^{\circ}\right.$ to $\left.20^{\circ}\right)$ thrust faults at shallow depths. The lateral extent of the imaged thrust faults are not known, but if the imaged fault is comparable to the mapped thrust faults to the north, the imaged fault is probably laterally connected to other thrust faults by high-angle faults. To the north, the imaged fault may also be connected to the mapped fault at depth, whereby both sole into one fault. The presence of such faults across most of the valley within San Gorgonio Pass, suggests that the hazards to the Pass, its infrastructure, and to through-going lifelines are greater than those from a single fault system located on the northern end of the Pass.

Because of the large number of seismic events recorded beneath, north, and south of San Gorgonio Pass between 1981 and 1993 (Magistrale and Sanders, 1996) and due to the presence of the regional lifelines trending through the Pass, it is clear that there is a considerable seismic risk within San Gorgonio Pass. Shaking induced by movement on local faults, such as those observed in the present seismic survey, or on the regional faults (San Andreas or San Jacinto) will likely be amplified by the thick (up to $200 \mathrm{~m}$ ) accumulation of low-velocity sediments that underlie most of San Gorgonio Pass.

Matti et al. (1992) suggest that surface faulting younger than about 2800 years has not yet been identified in the central San Gorgonio Pass region, but the seismic data from this study suggests that faults in the San Gorgonio River may propogate to the very near (within 3 meters or less) surface. Because of the flooding history in the area, it is likely that the faults identified in the seismic sections at only $3 \mathrm{~m}$ depth are relatively young. 
Trenching studies should be utilized within the San Gorgonio River to help date the apparent faults.

Future seismic risk assessments and hazard analyses should incorporate the results of the present study and more comprehensive investigations, utilizing a wide array of geological, geophysical, and hydrological methods, should be considered for the San Gorgonio Pass region to improve water-resource management and to mitigate hazards. 


\section{Data Availability}

The data are available as shot gathers with elevation and timing corrections applied in SEG-Y format from R.D. Catchings at the address in the front of this report.

\section{Acknowledgements}

We thank Jeff Dingler, Jamie Fenimore, Joseph Grow, Monique Jaasma, Gernot Lagand, Nicole Lautze, Janice Murphy, Keith Rice, Jose Rodriguez, and Marjan Rotting for assistance in acquiring the seismic data. The project was funded by the Morongo Indiar Reservation and the U. S. Geological Survey.

\section{References}

Allen, C.R., 1957,San Andreas fault zone in San Gorgonio Pass, southern California: Geological Society of America Bulletin, v. 68, p. 319-350.

Catchings, R. D., E. Horta, M. R. Goldman, M. J. Rymer, and T. R. Burdette, 1998, High-resolution seismic imaging for environmental and earthquake hazards assessment at the Raychem Site, Menlo Park, California, U. S. Geol. Surv. Open-File Report 98146, 37 pp.

Catchings, R. D., M. R. Goldman, W. H. K. Lee, M. J. Rymer and D. J. Ponti, 1998, Faulting Apparently Related to the 1994 Northridge, California, Earthquake and Possible Co-Seismic Origin of Surface Cracks in Potrero Canyon, Los Angeles County, California, Bull. Seism. Soc. Am. v.88,1379-1391.

Catchings, R.D., G. Gandhok, M.R. Goldman, E. Horta, M.J. Rymer, P. Martin, and A. Christensen, 1999, High-resolution seismic reflection/refraction imaging beneath Cherry Valley, Riverside County, California: Implications for water resources and earthquake hazards, U.S. Geol. Surv. Open-File Report 99-26, 60 pp.

Christensen, N. I. (1996). Poisson's ratio and crustal seismology, J. Geophys. Res. 101, 3139-3156.

Gandhok, G., R. D. Catchings, M.R. Goldman, E. Horta, M.J. Rymer, P. Martin, and A. Christensen, 1999, High-resolution seismic reflection/refraction imaging from I-10 to Cherry Valley Blvd., Cherry Valley, Riverside County, California: Implications for water resources and earthquake hazards, U.S. Geol. Surv. Open-File Report 99-320, $52 \mathrm{pp}$.

Fumal, T. E., J. F. Gibbs, and E. F. Roth 1981, In-situ measurements of seismic velocity at 19 locations in the Los Angeles, California region, U.S. Geol. surv. Open-File Rept. 81-399, 119 pp.

Fraser, D.M., 1931, Geology of the San Jacinto quadrangle south of San Gorgonio Pass: Calif. Div. Mines 27th Rept. of State Mineralogist, p.494-540.

Hole, J.A, 1992, Nonlinear high-resolution three-dimensional seismic travel time tomography, J. Geophys. Res., v. 97, p. 6553-6562. 
Magistrale, H. M., and C. Sanders, 1996, Evidence from precise earthquake hypocenters for segmentation of the San Andreas fault in San Gorgonio Pass, J. Geophys. Res., v. 101, 3031-3044.

Matti, J.C., D.M. Morton, B.F. Cox, 1992, Distribution and geologic relations of fault systems in the vicinity of the central Transverse Ranges, Southern California, Open-File Report 92-354.

Matti, J.C., and D.M. Morton, 1982, Geologic history of the Banning fault zone, southern California: Geological Society of America Abstracts with Programs,v.14, no.4,p. 184.

Mavko, G., T. Mukerji, and J. Dvorkin, 1996, Rock Physics Handbook, Stanford Rock physics Laboratory, Stanford University, Stanford, California, 323 pp.

Nur, Amos, 1982, Notes on wave propagation in porous rocks, Stanford Rock Physics Project vol. 13, Stanford, California, 121 pp.

Schon, J. H., 1996, Physical properties of rocks: Fundamentals and principles of petrophysics, Handbook of Geophysical Exploration (Seismic Exploration), v. 18, Pergamon Press, Elsevier Science, Inc., Tarrytown, New York, 583 pp. 


\section{Appendix A}

Distances and elevations along SG 1 seismic line.

Measurements are relative to first shotpoint at the west end of the line.

\begin{tabular}{|c|c|c|c|c|c|}
\hline Geophone Sta \# & Receiver Dist (m) & Receiver Elev. $(\mathrm{m})$ & Shot Sta. \# & Shot Distance $(\mathrm{m})$ & Shot Ele\% (m) \\
\hline & & & 1 & 0 & 11.67 \\
\hline & & & 3 & 10.22 & 11.75 \\
\hline & & & 5 & 19.6 & $11 . \subseteq 4$ \\
\hline & & & 7 & 30.37 & 11.59 \\
\hline & & & 9 & 40.09 & 11.42 \\
\hline & & & 13 & 50.32 & $11 . \approx 1$ \\
\hline & & & 15 & 60.21 & 11.2 \\
\hline & & & 17 & 69.78 & $11 . \mathrm{CS}^{2}$ \\
\hline & & & 19 & 80.32 & 10.71 \\
\hline & & & 21 & 90.13 & 10.51 \\
\hline & & & 23 & 100.01 & 10.49 \\
\hline 1 & 110.21 & 10.25 & 25 & 109.59 & 10.26 \\
\hline 2 & 115.11 & 10.09 & & & \\
\hline 3 & 120.2 & 10 & 27 & 119.98 & 9.92 \\
\hline 4 & 125.16 & 10.12 & & & \\
\hline 5 & 130.24 & 10.19 & 29 & 129.97 & 10.17 \\
\hline 6 & 135.19 & 10.11 & & & \\
\hline 7 & 140.5 & 10.17 & 31 & 140.43 & 9.96 \\
\hline 8 & 145.16 & 10.03 & & & \\
\hline 9 & 150.25 & 9.88 & 33 & 149.58 & 9.94 \\
\hline 10 & 155.21 & 9.99 & & & \\
\hline 11 & 160.31 & 9.98 & 35 & 160.19 & 9.88 \\
\hline 12 & 165.21 & 10.02 & & & \\
\hline 13 & 170.22 & 9.97 & 37 & 170.01 & 9.98 \\
\hline 14 & 175.33 & 10.04 & & & \\
\hline 15 & 180.24 & 9.95 & 39 & 180.1 & 9.84 \\
\hline 16 & 185.45 & 9.98 & & & \\
\hline 17 & 190.32 & 9.89 & 41 & 190.12 & 9.89 \\
\hline 18 & 195.24 & 9.95 & & & \\
\hline 19 & 200.23 & 9.64 & & & \\
\hline 20 & 205.21 & 9.42 & & & \\
\hline 21 & 210.38 & 9.72 & 43 & 211.25 & 9.77 \\
\hline 22 & 215.28 & 9.57 & & & \\
\hline 23 & 220.37 & 9.57 & 45 & 220.63 & 9.51 \\
\hline 24 & 225.18 & 9.5 & & & \\
\hline 25 & 230.3 & 9.68 & 47 & 230.1 & 9.63 \\
\hline 26 & 235.25 & 9.8 & & & \\
\hline 27 & 240.13 & 9.66 & 49 & 240.07 & 9.63 \\
\hline 28 & 245.15 & 9.42 & & & \\
\hline 29 & 250.21 & 9.36 & 51 & 249.73 & 9.25 \\
\hline
\end{tabular}




\begin{tabular}{|c|c|c|c|c|c|}
\hline 30 & 254.84 & 9.45 & & & \\
\hline 31 & 259.85 & 9.47 & 55 & 260.04 & 9.5 \\
\hline 32 & 265.02 & 9.45 & & & \\
\hline 33 & 270.12 & 9.41 & 57 & 270.03 & 9.41 \\
\hline 34 & 275.17 & 9.34 & & & \\
\hline 35 & 280.08 & 9.33 & 59 & 280.01 & 9.28 \\
\hline 36 & 285.04 & 9.16 & & & \\
\hline 37 & 290.22 & 9.1 & 61 & 290.14 & 9.07 \\
\hline 38 & 295.12 & 9.1 & & & \\
\hline 39 & 300.28 & 8.98 & 63 & 300.11 & 8.97 \\
\hline 40 & 305.36 & 9.07 & & & \\
\hline 41 & 310.39 & 8.97 & 65 & 310.3 & 8.91 \\
\hline 42 & 315.48 & 8.85 & & & \\
\hline 43 & 320.37 & 8.64 & 67 & 320.19 & 8.68 \\
\hline 44 & 325.3 & 8.6 & & & \\
\hline 45 & 330.28 & 8.48 & 69 & 330.36 & 8.4 \\
\hline 46 & 335.38 & 8.27 & & & \\
\hline 47 & 340.32 & 8.25 & 71 & 340.12 & 8.15 \\
\hline 48 & 345.44 & 8.1 & & & \\
\hline 49 & 350.44 & 7.98 & 73 & 350.28 & 7.91 \\
\hline 50 & 355.58 & 7.85 & & & \\
\hline 51 & 360.33 & 7.76 & 75 & 360.05 & 7.73 \\
\hline 52 & 365 & 7.81 & & & \\
\hline 53 & 370.31 & 7.73 & 77 & 369.99 & 7.71 \\
\hline 54 & 374.79 & 7.79 & & & \\
\hline 55 & 380.05 & 7.76 & 79 & 380.03 & 7.77 \\
\hline 56 & 384.82 & 7.52 & & & \\
\hline 57 & 390.08 & 7.51 & 81 & 390.17 & 7.51 \\
\hline 58 & 395.13 & 7.45 & & & \\
\hline 59 & 400.12 & 7.38 & 83 & 400.16 & 7.38 \\
\hline 60 & 404.93 & 7.3 & & & \\
\hline 61 & 409.98 & 7.29 & 85 & 410.03 & 7.2 \\
\hline 62 & 415.17 & 7.35 & & & \\
\hline 63 & 420.11 & 7.39 & 87 & 420.1 & 7.44 \\
\hline 64 & 425.05 & 7.32 & & & \\
\hline 65 & 430.03 & 7.31 & 89 & 430.07 & 7.27 \\
\hline 66 & 435.09 & 7.37 & & & \\
\hline 67 & 440.04 & 7.33 & 91 & 440.33 & 7.27 \\
\hline 68 & 445.02 & 7.3 & & & \\
\hline 69 & 449.95 & 7.35 & 93 & 449.79 & 7.26 \\
\hline 70 & 454.89 & 7.12 & & & \\
\hline 71 & 459.99 & 7.01 & 95 & 460.05 & 6.92 \\
\hline 72 & 465.34 & 6.89 & & & \\
\hline 73 & 469.81 & 6.76 & 97 & 469.73 & 6.69 \\
\hline 74 & 475.02 & 6.77 & & & \\
\hline 75 & 480.14 & 6.9 & 99 & 479.99 & 6.75 \\
\hline
\end{tabular}




\begin{tabular}{|c|c|c|c|c|c|}
\hline 76 & 484.9 & 6.67 & & & \\
\hline 77 & 489.96 & 6.63 & 101 & 489.97 & 6.6 \\
\hline 78 & 495.04 & 6.76 & & & \\
\hline 79 & 500.2 & 6.73 & 103 & 500.38 & 6.64 \\
\hline 80 & 504.9 & 6.78 & & & \\
\hline 81 & 510.09 & 6.67 & 105 & 510.25 & 6.62 \\
\hline 82 & 515.13 & 6.77 & & & \\
\hline 83 & 519.95 & 6.83 & 107 & 520 & 6.87 \\
\hline 84 & 524.72 & 6.75 & & & \\
\hline 85 & 529.9 & 6.62 & 109 & 530.11 & 6.55 \\
\hline 86 & 534.87 & 6.55 & & & \\
\hline 87 & 539.62 & 6.39 & 111 & 539.91 & 6.37 \\
\hline 88 & 544.64 & 6.37 & & & \\
\hline 89 & 549.83 & 6.32 & 113 & 549.57 & 6.29 \\
\hline 90 & 554.92 & 6.26 & & & \\
\hline 91 & 559.57 & 6.15 & 115 & 559.88 & 6.02 \\
\hline 92 & 565.02 & 6.04 & & & \\
\hline 93 & 569.97 & 5.72 & 117 & 570.59 & 5.75 \\
\hline 94 & 574.99 & 5.87 & & & \\
\hline 95 & 580.14 & 5.75 & 119 & 580.1 & 5.81 \\
\hline 96 & 584.83 & 5.78 & & & \\
\hline 97 & 589.88 & 5.46 & 121 & 590.3 & 5.47 \\
\hline 98 & 594.93 & 5.43 & & & \\
\hline 99 & 599.9 & 5.34 & 123 & 600.18 & 5.28 \\
\hline 100 & 604.98 & 5.31 & & & \\
\hline 101 & 610.04 & 5.1 & 125 & 610.24 & 5.2 \\
\hline 102 & 615.03 & 5.18 & & & \\
\hline 103 & 620.15 & 5.1 & 127 & 620.5 & 5.08 \\
\hline 104 & 625.16 & 5.04 & & & \\
\hline 105 & 630.17 & 4.88 & 129 & 629.94 & 4.77 \\
\hline 106 & 635.03 & 4.6 & & & \\
\hline 107 & 640.19 & 4.49 & 131 & 639.99 & 4.4 \\
\hline 108 & 645.35 & 4.34 & & & \\
\hline 109 & 649.85 & 4.37 & 133 & 650.2 & 4.28 \\
\hline 110 & 655.03 & 4.21 & & & \\
\hline 111 & 660.25 & 4 & 135 & 659.97 & 3.92 \\
\hline 112 & 664.82 & 3.93 & & & \\
\hline 113 & 669.86 & 3.68 & 139 & 669.8 & 3.63 \\
\hline 114 & 674.85 & 3.54 & & & \\
\hline 115 & 679.6 & 3.33 & 141 & 680 & 3.52 \\
\hline 116 & 685.2 & 3.37 & & & \\
\hline 117 & 690.18 & 3.47 & 143 & 690.13 & 3.41 \\
\hline 118 & 695.07 & 3.14 & & & \\
\hline 119 & 700.03 & 3.21 & 163 & 700.07 & 3.31 \\
\hline \multirow[t]{2}{*}{120} & 705.2 & 3.3 & & & \\
\hline & & & 165 & 710.16 & 3.1 \\
\hline
\end{tabular}




\begin{tabular}{|l|l|l||c|c|c|}
\hline & & & 167 & 720.25 & 2.94 \\
\hline & & & 169 & 729.85 & 2.67 \\
\hline & & & 171 & 739.61 & 2.22 \\
\hline & & & 173 & 750.23 & 2.12 \\
\hline & & & 177 & 759.9 & 1.64 \\
\hline & & & 179 & 769.68 & 1.05 \\
\hline & & & 181 & 780.01 & 1.01 \\
\hline & & & 183 & 790.07 & 0.54 \\
\hline & & & 185 & 810.22 & 0 \\
\hline
\end{tabular}




\section{Appendix B}

Distances and elevations along SG 2 seismic line.

Measurements are relative to first shotpoint at the south end of the line.

\begin{tabular}{|c|c|c|c|c|c|}
\hline Station No. & Receiver Dist. (m) & Receiver Elev. $(\mathrm{m})$ & Station No. & Shot Dist. $(\mathrm{m})$ & Shot Ele\%. $(\mathrm{m})$ \\
\hline & & & 1 & 0 & 1.08 \\
\hline & & & & & \\
\hline & & & 3 & 10.08 & 0.85 \\
\hline & & & & & \\
\hline & & & 5 & 20.23 & 1 \\
\hline & & & & & \\
\hline & & & 7 & 29.64 & 0.91 \\
\hline & & & & & \\
\hline & & & 9 & 39.53 & 1.23 \\
\hline & & & & & \\
\hline & & & 13 & 59.39 & 0.98 \\
\hline & & & & & \\
\hline & & & 15 & 70.05 & 0.81 \\
\hline & & & & & \\
\hline & & & 17 & 79.61 & 0.51 \\
\hline & & & & & \\
\hline & & & 19 & 89.36 & 0.43 \\
\hline & & & & & \\
\hline & & & 21 & 99.39 & 0.53 \\
\hline 23 & 10938 & 039 & 23 & 10938 & 039 \\
\hline 24 & 114.58 & 0.41 & & & \\
\hline 25 & 119.75 & 0.42 & 25 & 119.75 & 0.42 \\
\hline 26 & 124.63 & 0.66 & & & \\
\hline 27 & 129.78 & 0.55 & 27 & 129.74 & 0.45 \\
\hline 28 & 134.56 & 0.64 & & & \\
\hline 29 & 139.39 & 0.46 & 29 & 139.58 & 0.39 \\
\hline 30 & 144.62 & 0.47 & & & \\
\hline 31 & 149.91 & 0.47 & 31 & 149.11 & 0.46 \\
\hline 32 & 154.82 & 0.5 & & & \\
\hline 33 & 159.89 & 0.47 & 33 & 159.05 & 0.46 \\
\hline 34 & 164.89 & 0.61 & & & \\
\hline 35 & 169.38 & 1.07 & 35 & 169.41 & 1.02 \\
\hline 36 & 174.35 & 0.94 & & & \\
\hline 37 & 179.27 & 0.56 & 37 & 179.44 & 0.48 \\
\hline 38 & 184.21 & 0.55 & & & \\
\hline 39 & 189.32 & 0.51 & 39 & 189.48 & 0.55 \\
\hline 40 & 194.41 & 1.27 & & & \\
\hline 41 & 199.15 & 0.38 & 41 & 199.31 & 0.39 \\
\hline 42 & 204.4 & 0.61 & & & \\
\hline
\end{tabular}




\begin{tabular}{|c|c|c|c|c|c|}
\hline 43 & 209.4 & 0.69 & 43 & 209.29 & 0.63 \\
\hline 44 & 214.18 & 0.44 & & & \\
\hline 45 & 219.14 & 0.48 & 45 & 219.78 & 0.47 \\
\hline 46 & 224.51 & 0.28 & & & \\
\hline 47 & 229.68 & 0.5 & 47 & 229.96 & 0.17 \\
\hline 48 & 234.35 & 0.26 & & & \\
\hline 49 & 239.6 & 0.14 & 49 & 239.62 & 0.15 \\
\hline 50 & 244.41 & 0.4 & & & \\
\hline 51 & 249.59 & 0.15 & 51 & 249.47 & 0.1 \\
\hline 52 & 254.34 & 0.35 & & & \\
\hline 53 & 259.41 & 0.49 & & & \\
\hline 54 & 264.37 & 0.09 & & & \\
\hline 55 & 269.35 & 0.65 & 55 & 269.26 & 0.52 \\
\hline 56 & 274.42 & 0.64 & & & \\
\hline 57 & 279.64 & 0.8 & 57 & 279.48 & 0.52 \\
\hline 58 & 284.66 & 0.51 & & & \\
\hline 59 & 289.61 & 0.49 & 59 & 289.62 & 0.43 \\
\hline 60 & 294.68 & 0.62 & & & \\
\hline 61 & 299.31 & 0.91 & 61 & 299.43 & 0.71 \\
\hline 62 & 304.14 & 1.59 & & & \\
\hline 63 & 309.44 & 1.87 & 63 & 309.05 & 1.9 \\
\hline 64 & 314.42 & 1.77 & & & \\
\hline 65 & 319.32 & 2.3 & 65 & 319.05 & 2.09 \\
\hline 66 & 323.86 & 1.76 & & & \\
\hline 67 & 329.03 & 1.34 & 67 & 328.78 & 1.24 \\
\hline 68 & 334.04 & 0.65 & & & \\
\hline 69 & 339.25 & 0.85 & 69 & 339.24 & 0.63 \\
\hline 70 & 344.14 & 0.74 & & & \\
\hline 71 & 349.38 & 0.42 & 71 & 348.93 & 0.49 \\
\hline 72 & 354.28 & 0.64 & & & \\
\hline 73 & 359.27 & 0.39 & 73 & 358.59 & 0.48 \\
\hline 74 & 363.97 & 0.37 & & & \\
\hline 75 & 368.9 & 0.46 & 75 & 368.86 & 0.53 \\
\hline 76 & 374.29 & 0.46 & & & \\
\hline 77 & 379.34 & 0.42 & 77 & 379.27 & 0.43 \\
\hline 78 & 384.48 & 0.53 & & & \\
\hline 79 & 389.1 & 0.05 & 79 & 389.15 & 0 \\
\hline 80 & 394.18 & 0.42 & & & \\
\hline 81 & 399.53 & 0.43 & 81 & 399.5 & 0.48 \\
\hline 82 & 404.61 & 0.43 & & & \\
\hline 83 & 409.6 & 0.53 & 83 & 409.53 & 0.44 \\
\hline 84 & 414.26 & 0.65 & & & \\
\hline 85 & 419.36 & 0.31 & 85 & 419.23 & 0.35 \\
\hline 86 & 424.52 & 0.32 & & & \\
\hline 87 & 429.31 & 0.35 & 87 & 429.84 & 0.34 \\
\hline 88 & 434.24 & 0.61 & & & \\
\hline
\end{tabular}




\begin{tabular}{|c|c|c|c|c|c|}
\hline 89 & 439.38 & 0.96 & 89 & 439.62 & 0.99 \\
\hline 90 & 444.32 & 1.65 & & & \\
\hline 91 & 449.04 & 3.73 & 91 & 449.11 & 3.55 \\
\hline 92 & 453.48 & 5.88 & & & \\
\hline 93 & 458.1 & 7.99 & 93 & 458.7 & 7.7 \\
\hline 94 & 463.32 & 9.03 & & & \\
\hline 95 & 468 & 9.31 & 95 & 468.29 & 9.3 \\
\hline 96 & 472.81 & 9.45 & & & \\
\hline 97 & 477.72 & 9.39 & 97 & 477.83 & 9.3 \\
\hline 98 & 483.23 & 9.64 & & & \\
\hline 99 & 488.16 & 9.68 & 99 & 488.29 & 9.63 \\
\hline 100 & 493.45 & 9.86 & & & \\
\hline 101 & 498.29 & 10.02 & 101 & 498.1 & 9.92 \\
\hline 102 & 503.17 & 10.27 & & & \\
\hline 103 & 507.82 & 10.31 & 103 & 508.13 & 10.28 \\
\hline 104 & 512.64 & 10.43 & & & \\
\hline 105 & 518.23 & 10.63 & 105 & 517.93 & 10.45 \\
\hline 106 & 522.84 & 10.65 & & & \\
\hline 107 & 528.28 & 10.92 & 107 & 528.08 & 10.9 \\
\hline 108 & 532.59 & 11.01 & & & \\
\hline 109 & 537.79 & 11.16 & 109 & 537.71 & 11.02 \\
\hline 110 & 543.28 & 11.3 & & & \\
\hline 111 & 547.98 & 11.32 & 111 & 547.98 & 11.29 \\
\hline 112 & 552.87 & 11.59 & & & \\
\hline 113 & 558 & 11.57 & 113 & 557.97 & 11.53 \\
\hline 114 & 562.88 & 11.7 & & & \\
\hline 115 & 568.27 & 11.97 & 115 & 568.03 & 11.94 \\
\hline 116 & 573.08 & 12.1 & & & \\
\hline 117 & 578.04 & 12.16 & 117 & 578.1 & 12.19 \\
\hline 118 & 583.29 & 12.48 & & & \\
\hline 119 & 588.04 & 12.65 & 119 & 588.07 & 12.6 \\
\hline 120 & 592.88 & 12.81 & & & \\
\hline 121 & 597.89 & 12.97 & 121 & 598.07 & 13.01 \\
\hline 122 & 603.1 & 13.4 & & & \\
\hline 123 & 608.35 & 13.46 & 123 & 608.17 & 13.37 \\
\hline 124 & 613.25 & 13.63 & & & \\
\hline 125 & 618.36 & 13.75 & 125 & 618.21 & 13.74 \\
\hline 126 & 623.14 & 14 & & & \\
\hline 127 & 628.05 & 13.96 & 127 & 627.94 & 13.86 \\
\hline 128 & 633.4 & 14.17 & & & \\
\hline 129 & 638.07 & 14.27 & 129 & 638.12 & 14.19 \\
\hline 130 & 642.8 & 14.29 & & & \\
\hline 131 & 648.25 & 14.6 & 131 & 648.22 & 14.52 \\
\hline 132 & 653.27 & 14.5 & & & \\
\hline 133 & 657.95 & 14.27 & 133 & 658.07 & 14.24 \\
\hline 134 & 663.17 & 14.66 & & & \\
\hline
\end{tabular}




\begin{tabular}{|c|c|c|c|c|c|}
\hline 135 & 668.2 & 15.24 & 135 & 668.24 & 15.26 \\
\hline 136 & 673.29 & 15.71 & & & \\
\hline 137 & 678 & 15.98 & & & \\
\hline 138 & 683.28 & 15.53 & & & \\
\hline 139 & 688.29 & 15.72 & 139 & 688.13 & 15.67 \\
\hline 140 & 693.36 & 15.78 & & & \\
\hline 141 & 698.37 & 15.9 & 141 & 698.31 & 15.93 \\
\hline 142 & 703.15 & 16.06 & & & \\
\hline 143 & 708.15 & 18 & 143 & 707.66 & 16.46 \\
\hline 144 & 713.15 & 18 & & & \\
\hline 145 & 718.15 & 18 & & & \\
\hline 146 & 723.15 & 18 & & & \\
\hline 147 & 728.15 & 18 & & & \\
\hline 148 & 733.15 & 18 & & & \\
\hline 149 & 738.15 & 18 & & & \\
\hline 150 & 743.15 & 18 & & & \\
\hline 151 & 748.15 & 18 & & & \\
\hline 152 & 753.15 & 18 & & & \\
\hline 153 & 758.15 & 18 & & & \\
\hline 154 & 763.15 & 18 & & & \\
\hline 155 & 768.15 & 18 & & & \\
\hline 156 & 773.15 & 18 & & & \\
\hline 157 & 778.15 & 18 & & & \\
\hline 158 & 783.15 & 18 & & & \\
\hline 159 & 788.15 & 18 & & & \\
\hline 160 & 793.15 & 18 & & & \\
\hline 161 & 798.15 & 18 & & & \\
\hline 162 & 803.15 & 18 & & & \\
\hline 163 & 808.15 & 18 & 163 & 810.54 & 20.48 \\
\hline 164 & 815.13 & 20.59 & & & \\
\hline 165 & 820.4 & 20.64 & 165 & 820.52 & 20.58 \\
\hline 166 & 825.36 & 20.67 & & & \\
\hline 167 & 830.31 & 20.91 & 167 & 830.47 & 20.8 \\
\hline 168 & 835.35 & 21.15 & & & \\
\hline 169 & 840.41 & 21.36 & 169 & 840.33 & 21.3 \\
\hline 170 & 845.4 & 21.54 & & & \\
\hline 171 & 850.48 & 21.73 & 171 & 851 & 21.74 \\
\hline 172 & 855.39 & 21.92 & & & \\
\hline 173 & 860.39 & 22.22 & 173 & 860.64 & 22.14 \\
\hline 174 & 865.42 & 22.4 & & & \\
\hline 175 & 870.22 & 22.64 & & & \\
\hline 176 & 875.47 & 22.8 & & & \\
\hline 177 & 880.33 & 23.02 & 177 & 880.23 & 22.95 \\
\hline 178 & 885.3 & 23.02 & & & \\
\hline 179 & 890.28 & 23.45 & 179 & 890.34 & 23.25 \\
\hline 180 & 895.23 & 23.71 & & & \\
\hline
\end{tabular}




\begin{tabular}{|c|c|c|c|c|c|}
\hline 181 & 900.27 & 23.93 & 181 & 900.35 & 23.77 \\
\hline 182 & 905.51 & 24.25 & & & \\
\hline 183 & 910.38 & 24.47 & 183 & 910.38 & 24.32 \\
\hline 184 & 915.32 & 24.7 & & & \\
\hline 185 & 920.37 & 24.89 & 185 & 920.4 & 24.89 \\
\hline 186 & 925.33 & 25.11 & & & \\
\hline 187 & 930.26 & 25.34 & 187 & 930.38 & 25.17 \\
\hline 188 & 935.26 & 25.61 & & & \\
\hline 189 & 940.21 & 25.8 & 189 & 940.21 & 25.74 \\
\hline 190 & 945.22 & 25.94 & & & \\
\hline 191 & 950.2 & 26.21 & 191 & 950.21 & 26.24 \\
\hline 192 & 955.23 & 26.45 & & & \\
\hline 193 & 960.16 & 26.72 & 193 & 959.94 & 26.61 \\
\hline 194 & 965.31 & 26.85 & & & \\
\hline 195 & 970.19 & 27.06 & 195 & 970.32 & 26.91 \\
\hline 196 & 975.27 & 27.19 & & & \\
\hline 197 & 980.16 & 27.38 & 197 & 980.13 & 27.33 \\
\hline 198 & 985.11 & 27.53 & & & \\
\hline 199 & 990.25 & 27.72 & 199 & 990.45 & 27.59 \\
\hline 200 & 995.1 & 27.93 & & & \\
\hline 201 & 999.99 & 28.18 & 201 & 999.9 & 27.95 \\
\hline 202 & 1005.28 & 28.41 & & & \\
\hline 203 & 1010.13 & 28.69 & 203 & 1010.07 & 28.6 \\
\hline 204 & 1015.31 & 28.96 & & & \\
\hline 205 & 1020.19 & 29.21 & 205 & 1020.19 & 29.14 \\
\hline 206 & 1025.19 & 29.37 & & & \\
\hline 207 & 1030.31 & 29.62 & 207 & 1030.2 & 29.5 \\
\hline 208 & 1035.14 & 29.75 & & & \\
\hline 209 & 1040 & 29.88 & 209 & 1040.17 & 29.88 \\
\hline 210 & 1045.06 & 30.14 & & & \\
\hline 211 & 1050.08 & 30.3 & 211 & 1050.1 & 30.32 \\
\hline 212 & 1055.1 & 30.65 & & & \\
\hline 213 & 1059.9 & 30.96 & 213 & 1059.77 & 30.96 \\
\hline 214 & 1064.91 & 30.89 & & & \\
\hline 215 & 1070.14 & 31.17 & 215 & 1070.09 & 31.07 \\
\hline 216 & 1075.08 & 31.36 & & & \\
\hline 217 & 1079.71 & 31.71 & 217 & 1079.79 & 31.71 \\
\hline 218 & 1084.86 & 31.93 & & & \\
\hline 219 & 1089.94 & 32.18 & 219 & 1089.97 & 32.18 \\
\hline 220 & 1095 & 32.41 & & & \\
\hline 221 & 1099.89 & 32.57 & 221 & 1099.77 & 32.56 \\
\hline 222 & 1105.44 & 32.71 & & & \\
\hline 223 & 1110.05 & 32.95 & 223 & 1109.98 & 32.85 \\
\hline 224 & 1115.25 & 33.2 & & & \\
\hline 225 & 1119.9 & 33.58 & 225 & 1120.13 & 33.34 \\
\hline 226 & 1124.71 & 33.85 & & & \\
\hline
\end{tabular}




\begin{tabular}{|c|c|c|c|c|c|}
\hline 227 & 1129.89 & 34.06 & 227 & 1129.63 & 33.92 \\
\hline 228 & 1134.77 & 34.39 & & & \\
\hline 229 & 1139.6 & 34.59 & 229 & 1139.68 & 34.4 \\
\hline 230 & 1144.65 & 34.69 & & & \\
\hline 231 & 1149.89 & 35.09 & 231 & 1149.67 & 35.04 \\
\hline 232 & 1154.55 & 35.33 & & & \\
\hline 233 & 1159.73 & 35.56 & 233 & 1160.02 & 35.43 \\
\hline 234 & 1164.67 & 35.83 & & & \\
\hline 235 & 1169.83 & 36.03 & 235 & 1169.8 & 35.9 \\
\hline 236 & 1174.43 & 36.2 & & & \\
\hline 237 & 1179.63 & 36.28 & 237 & 1179.3 & 36.27 \\
\hline 238 & 1184.51 & 36.57 & & & \\
\hline 239 & 1189.5 & 36.84 & 239 & 1189.43 & 36.6 \\
\hline 240 & 1194.31 & 36.93 & & & \\
\hline 241 & 1199.07 & 37.06 & 241 & 1198.89 & 36.93 \\
\hline 242 & 1203.98 & 37.32 & & & \\
\hline 243 & 1209.45 & 37.57 & 243 & 1209.21 & 37.36 \\
\hline 244 & 1214.17 & 37.81 & & & \\
\hline 245 & 1218.92 & 38.04 & 245 & 1218.87 & 37.88 \\
\hline 246 & 1224.1 & 38.4 & & & \\
\hline 247 & 1229.1 & 38.54 & 247 & 1229.22 & 38.55 \\
\hline 248 & 1234.05 & 38.88 & & & \\
\hline 249 & 1239.17 & 39.06 & 249 & 1238.84 & 38.97 \\
\hline 250 & 1243.84 & 39.3 & & & \\
\hline 251 & 1248.74 & 39.47 & 251 & 1248.69 & 39.47 \\
\hline 252 & 1253.87 & 39.73 & & & \\
\hline 253 & 1258.65 & 39.98 & 253 & 1258.85 & 39.93 \\
\hline 254 & 1263.71 & 40.27 & & & \\
\hline 255 & 1268.58 & 40.45 & 255 & 1268.85 & 40.35 \\
\hline 256 & 1273.59 & 40.72 & & & \\
\hline 257 & 1278.84 & 41.02 & 257 & 1278.83 & 40.89 \\
\hline 258 & 1283.4 & 41.33 & & & \\
\hline 259 & 1288.59 & 41.61 & 259 & 1288.33 & 41.33 \\
\hline 260 & 1293.32 & 41.81 & & & \\
\hline 261 & 1298.7 & 42.14 & 261 & 1298.57 & 41.95 \\
\hline 262 & 1303.28 & 42.31 & & & \\
\hline 263 & 1308.25 & 42.52 & 263 & 1307.69 & 42.49 \\
\hline 264 & 1313.48 & 42.79 & & & \\
\hline 265 & 1318.18 & 42.97 & 265 & 1318.1 & 42.89 \\
\hline 266 & 1323.39 & 43.08 & & & \\
\hline 267 & 1328.77 & 43.37 & 267 & 1328.94 & 43.45 \\
\hline 268 & 1333.81 & 43.67 & & & \\
\hline 269 & 1338.73 & 43.88 & 269 & 1338.81 & 43.8 \\
\hline 270 & 1343.49 & 44.28 & & & \\
\hline 271 & 1348.38 & 44.48 & 271 & 1348.35 & 44.37 \\
\hline 272 & 1353.21 & 44.99 & & & \\
\hline
\end{tabular}




\begin{tabular}{|c|c|c|c|c|c|}
\hline 273 & 1358.4 & 45.42 & 273 & 1358.16 & 44.85 \\
\hline 274 & 1363.3 & 46 & & & \\
\hline 275 & 1368.18 & 46.25 & 275 & 1368.27 & 45.44 \\
\hline 276 & 1373.11 & 46.88 & & & \\
\hline 277 & 1378.01 & 46.54 & 277 & 1378.23 & 46.66 \\
\hline 278 & 1382.99 & 46.92 & & & \\
\hline 279 & 1387.65 & 47.49 & 279 & 1387.91 & 47.77 \\
\hline 280 & 1392.4 & 47.91 & & & \\
\hline 281 & 1397.59 & 48.38 & 281 & 1397.55 & 48.87 \\
\hline 282 & 1402.3 & 49.05 & & & \\
\hline \multirow[t]{11}{*}{283} & 1407 & 49.76 & 297 & 1477.36 & 51.47 \\
\hline & & & & & \\
\hline & & & 301 & 1497.81 & 52.18 \\
\hline & & & 303 & 1507.31 & 52.79 \\
\hline & & & & & \\
\hline & & & 307 & 1527.77 & 53.87 \\
\hline & & & & & \\
\hline & & & 309 & 1537.37 & 54.5 \\
\hline & & & & & \\
\hline & & & 315 & 1566.98 & 56.19 \\
\hline & & & 317 & 157745 & 5669 \\
\hline & & & & & \\
\hline & & & & & \\
\hline & & & & & \\
\hline & & & & & \\
\hline & & & & & \\
\hline & & & & & \\
\hline & & & & & \\
\hline & & & & & \\
\hline & & & & & \\
\hline & & & & & \\
\hline & & & & & \\
\hline & & & & & \\
\hline & & & & & \\
\hline & & & & & \\
\hline & & & & & \\
\hline & & & & & \\
\hline & & & & & \\
\hline & & & & & \\
\hline & & & & & \\
\hline & & & & & \\
\hline & & & & & \\
\hline & & & & & \\
\hline & & & & & \\
\hline
\end{tabular}

